\title{
(@) $(1)$
}

Revista Tempo - Técnica - Território http://periodicos.unb.br/index.php/ciga está licenciado com uma Licença Creative Commons - Atribuição-NãoComercial 4.0 Internacional.

Podem estar disponíveis autorizações adicionais às concedidas no âmbito desta licença em http://periodicos.unb.br/index.php/ciga.

Fonte: https://periodicos.unb.br/index.php/ciga/article/view/22255. Acesso em: 10 ago. 2020.

\section{REFERÊNCIA}

GOULARD, Nilton; ANJOS, Rafael Sanzio Araújo dos. Social environmental conflicts in the basin stream of fern, Distrito Federal - Brasil. Revista Tempo - Técnica - Território, Brasília, v. 3, n. 1, p. 101-143, 2012. DOI: https://doi.org/10.26512/ciga.v3i1.22255. Disponível em:

https://periodicos.unb.br/index.php/ciga/article/view/22255. Acesso em: 10 ago. 2020. 


\title{
SOCIAL ENVIRONMENTAL CONFLICTS IN THE BASIN STREAM OF FERN, DISTRITO FEDERAL - BRASIL
}

\author{
NILTON GOULARD \\ Mestrado em Geografia. \\ UnB - Universidade de Brasília \\ Bacharel em Engenharia Florestal pela Universidade de Brasília \\ Email: goulart.sousa@gmail.com
}

\section{RAFAEL SANZIO ARAÚJO DOS ANJOS}

Geógrafo (UFBa.), Doutor em Informações Espaciais (POLIUSP-BR/IRD-FR.), PósDoutorado Cartografia Étnica (MRAC-BE). Prof. Associado do Depto. de Geografia da Universidade de Brasília (UnB) / Diretor do Centro de Cartografia Aplicada e Informação Geográfica da UnB e Coordenador do Projeto Geografia Afro-Brasileira: Educação \& Planejamento do Território.

Tel: 55(61)3107-7242 E-mail:cartografia@unb.br Site:www.unb.br/ih/ciga \& www.rafaelsanziodosanjos.com.br

RESUMO: The environmental thematic subject can also be seen under the optics of the conflict, since the natural resources are be objects of disputes and interests. The subjects of the environment can be classified according to types different from conflict and they elapse of the dispute or misunderstanding related with the exploration of the natural resources, tending to increase with the shortage and competition for the natural resource. In the end of the century 20 the conflicts related with environment began to be studied under that environmental vision. That happened with the proposition of a new model, call of maintainable development that looks for a composition among the factors economical, social and environmental. In the concept of the maintainable development, the interests that were in conflict now they necessarily need to be composed. An example of the observation of the environmental subjects under the optics of the conflicts, is Distrito Federal (DF) a Brazilian state and it's Integrated Area of Economical Development, whose population expanded without projects for use and occupation of the territory. The present work explains the dynamics and the space expression of a environmental conflict Samambaia's stream, in DF. Stage of an intense territorial occupation in a short space of time, promoting a fast change of the landscape and the consequences of that drastic change. With to present researches, it was noticed that model of occupation of the territory doesn't differ of other similar units in DF, in face to the accelerated urbanization and the absences and incongruities in the state public politics for the habitation demand. It was evident that the access difficulty to the 
earth for legal means stimulates part of the society to look for other mechanisms, for illicit times, to satisfy your habitation demand. That fact associated to the ineffective territorial administration by the part of the Brazilian State and added to migratory processes and the real estate speculation, they foment the environmental compromising and the appearance of environmental conflicts in the Samambaia's. As main actors of the conflict met residents, the DF government and the Brazilian government, both with your different organs. For solutions it is suggested cooperation mechanisms, being looked for consent. It was noticed that wrap up actors of several slopes in that conflict, with asymmetric relationships of being able to.

Key words: territory use, urban growth, environmental conflict, drainage water basin, territory administration, samambaia stream, DF

RESUMO: A questão da temática ambiental pode também ser vista sob a ótica do conflito, já que os recursos naturais são e serão objetos de disputas e interesses. Sob essa égide, as questões do meio ambiente podem ser classificadas segundo tipos diferentes de conflito, e decorrem da disputa ou desentendimento relacionados com o uso e/ou exploração dos recursos naturais, tendendo a aumentar com a escassez e competição pelo bem natural. No final do século 20 os conflitos relacionados ao meio ambiente começaram a ser estudados sob essa visão "sócio-ambiental". Isso ocorreu com a proposição de um novo modelo, chamado de desenvolvimento sustentável, que busca uma composição entre os fatores econômico, social e ambiental. Na implementação do desenvolvimento sustentável, os interesses que eram conflitantes e excludentes agora necessariamente precisam ser compostos. Um exemplo da observação das questões ambientais sob a ótica dos conflitos, é o Distrito Federal e sua Região Integrada de Desenvolvimento Econômico - RIDE, cuja população expandiu com a implementação fragmentada de projetos de uso e ocupação do território. Nesse contexto, o presente trabalho buscou explicar a dinâmica e a expressão espacial de um conflito sócio-ambiental ocorrente na micro-bacia do Rio Samambaia, no DF. Palco de uma intensa ocupação territorial em um curto espaço de tempo, promovendo uma rápida mudança da paisagem, hoje as conseqüências dessa drástica mudança. Com a presente pesquisa, percebeu-se que esse modelo de ocupação do território não difere de outras unidades semelhantes no DF, em face à urbanização acelerada e as ausências e incongruências nas políticas públicas estatais para a demanda habitacional. Ficou evidente que a dificuldade de acesso à terra por meios legais estimula parte da sociedade a buscar outros mecanismos, por vezes ilícitos, para satisfazer sua demanda habitacional. Esse fato associado à ineficaz gestão territorial por parte do Estado e somado a processos migratórios e à especulação imobiliária, fomentam o comprometimento ambiental e a eclosão de conflitos sócio-ambientais na micro-bacia do Rio Samambaia. Como principais atores do conflito encontrou-se moradores, o governo do Distrito Federal e a União, ambos com seus distintos órgãos. Para a busca de soluções sugere-se mecanismos de diálogo/cooperação, buscando-se consenso. 
Percebeu-se que nesse conflito envolvem-se atores de diversas vertentes, com relações assimétricas de poder.

Palavras-chave: uso do território, crescimento urbano, conflito sócio-ambiental, bacia de drenagem, gestão do território, rio samambaia, Distrito Federal

RESUMEN: Las cuestiones medioambientales también puede verse bajo las ópticas del conflicto, desde que los recursos naturales son objetos de disputas e intereses. Los asuntos del ambiente pueden ser clasificados según los tipos diferente del conflicto y ellos pasan de la disputa o entendiendo mal relacionaron con la exploración de los recursos naturales, mientras tendiendo a aumentar con la escasez y competición para el recurso natural. En el fin del siglo 20, los conflictos relacionados con el ambiente empezaron a ser estudiados bajo esa visión medioambiental. Eso pasó con la proposición de un nuevo modelo, llamado de desarrollo sustenible que busca una composición entre los factores sociales y medioambientales. En el concepto del desarrollo sustenible, los intereses que estaban ahora en el conflicto que ellos necesariamente necesitan ser compuestos. Un ejemplo de la observación de los asuntos medioambientales bajo las ópticas de los conflictos, es Distrito Federal (DF) un estado brasileño y Área de Desarrollo Económico, cuya población extendió sin los proyectos para el uso y ocupación del territorio. El trabajo presente explica la dinámica y la expresión espacial de un conflicto medioambiental em el arroyo de Samambaia, en DF. La fase de una intensa ocupación territorial en un espacio corto de tiempo, promoviendo un cambio rápido del paisaje y las consecuencias de ese cambio drástico. En esse proceso, fue notado que modelo de ocupación del territorio no difiere de otras unidades similares en DF, con urbanización acelerada y las ausencias e incongruencias en la política pública estatal para la demanda de la habitación. Era evidente que la dificultad de acceso a la tierra por medios legales estimula parte de la sociedad para buscar otros mecanismos, para satisfacer su demanda de la habitación. Ese hecho asoció a la administración territorial ineficaz por la parte del Estado brasileño y agregó a los procesos migratorios y la especulación de tierras. Eso fomenta factores de conflictos medioambientales en el Arroyo Samambaia's. Como los actores principales del conflicto existem los residentes, el gobierno de DF y el gobierno brasileño, ambos con sus órganos diferentes, se encontraron. Para las soluciones se hace pensar en mecanismos de cooperación, pareciéndose para el consentimiento. Fue notado que la envoltura a actores de varias cuestas en ese conflicto, con las relaciones asimétricas.

Palabra clave: uso del territorio, el crecimiento urbano, conflicto medioambiental, cuenca, administración del territorio, Arroyo Samambaia, Distrito Federal 


\section{Introduction}

Federal District - DF, with an area of $5.814 \mathrm{~km} 2$ and a population of approximately 2.000.000 of inhabitants (CODEPLAN, 2006) it is placed in an area of high lands that serve as a center of the drainages that flow for four important drainage-water basins of Brazil: Silver, Araguaia, Tocantins and São Francisco. It's totally meets inserted in "Cerrado" landscape (Savannah), one of the richest in biodiversity of the planet, and $40 \%$ of your territory are inserted in the Reservation of the Biosphere of the Savannah, created by Unesco in the program " Biosphere ". (UNESCO, 2000)

In the period of 1980 - 2000, by virtue of the fort population growth and of the intensification of the economical activities in the agricultural section and of services in $\mathrm{DF}$, a strong pressure is verified on the natural resources, being placed in your risk maintainable use.

The maintainable of the regional development will owe, more and more intensely, to rule for the warranty of the balance among the actions gone back to the promotion of the economical growth and the conservation of the environment.

This way, there is the need of changes of some paradigms of the development, such as, the rationalization environmental resources, planned territorial occupation and the decrease of the social inequalities. Before 1998, DF had lost more than $75 \%$ of your original covering of savannah and $25 \%$ of the forest areas (UNESCO, 2000).

Now in DF, can found already perceptible situations of serious environmental conflicts with relationship to the occupation of the territory and water resources, that already assume preoccupying proportions.

One of the places that is model of expression of that fact is Samambaia's stream Water basin. This suffered starting from the decade of 60, an occupation process disordered and that culminates now with a stage or arena of actors' confrontation involved in different positioning and actions, in what refers to the demand for natural resources, aspects land and also political.

In the distrital sphere, it is noticed that the government place has not been getting to contain the irregular occupations. The current environmental aggressions of that model continue happening. Irregular condominiums proliferate and the legalization process has not been getting to reach consent among them involved. The proprietors and residents while they await a position of the government they build constructions without orientation or planning, for times in risk areas. The problems appear, deforestation of rivers and nascent, contamination of sheet water and diseases. Due to the irregularities and of the possibility to lose the investment, proprietors accelerate the occupation and they promote an environmental degradation every time larger. The government reacts with punctual demolitions. 
The present study has as main objective to identify and to analyze the structural components of the existent environmental conflicts in the occupation process and territorial transformation in Samambaia's stream. The head office of that environmental conflict analysis bases political environmental and cultural and also in characteristics physics of the water water basin, such as vegetation and the water system. It is exactly the crossing of that information, associated to the occupation process and territorial transformation, which supplies the conflict structure. It is worth to point choice as unit of geographical analysis since this makes possible an administration structured by the interaction of physical conditions of the area and for the socioeconomic and cultural conditions of the population that she shelters. The water basin in subject locates in the principal axis of development of DF, which is the area between Taguatinga and the Pilot Plan. The methodological procedures developed for the investigation they look for the understanding of the conflict model, your processes and actors can serve as base for other studies of that nature in DF and in Central Brazil.

The methodology of this work is structured in two basic and related parts. The first refers to the study and characterization of the use of the territory in the water basin in time scale and the space identification of structural components and actors of conflict presents in the water basin. The integrated analysis of the information of the two stages will allow the characterization of the environmental conflict. The reference is that this study is also a contribution for origin processes and dynamics of conflicts, by a case study. A rising of data was made on the use multi-storm of the territory in the water basin to know the characteristics and environmental conditions and together with the social and economic conditions, to constitute the base for the elaboration and characterization of the conflict in subject. It was looked for with that to base measures that can aid in the conservation of the natural resources of that place and to reconcile these with the human occupation.

With that it was looked for to understand the results of the adoption of punctual solutions to solve the territorial problems in DF, which not generate impasses due to the reality of habitation demands assisted and that ends for stimulating the irregularity as model of territorial occupation. The final products of the territorial study occupation, letter synthesis of the conflicts, they make possible suggestions to the community and government for to present alternatives o balance urban expansion with the preservation of the local natural way.

\section{Concepts and Methodological Procedures}

\subsection{The Territory Concept}

The word territory refers to an area delimited under a person's ownership (or people's group), of an organization or an institution. The term is used in the politics referring to the Nation/State. There are several senses for the word territory, but all share of the idea of appropriation of a geographical portion for an individual or a collectivity. The term "territory" is also used to identify states not independent and subordinate, even certain 
degree, to an external power. Different territory categories exist, in agreement with the dependence relationships. (CORRÊA \& ROSENTHAL, 1998).

In that way it can understand each other the territory as the space manifestation of the power based in social relationships in different degrees, for the presence of actions and concrete structures and of information. That understanding allows to think the territory formation process, based, above all, in the accessibility degree to the information; in other words, the information, or not, of symbols of meanings they can make to appear new territories, to destroy them or to reconstruct them (RAFFESTIN 1993).

\subsection{Landscape}

In a classic vision, landscape is the materialized expression of the man's relationships with the nature in a bounded space (SCHIER, 2003). However, the landscape, is something besides the visible, resultant of an articulation process among your constituent elements, be them of order exclusively natural (natural landscapes) or of human order (cultural landscapes) (TROLL, 1982).

Milton Santos's concept of landscape as being the materialized expression of the geographical space, defining it as " the group in ways that, in a die moment, they express the inheritances that represent the successive located relationships between the man and the nature ". Santos differentiate space landscape: where that is "temporal " joining last and present objects, a traverse construction joining objects and this is always a present, a horizontal construction, an only situation. Or still, landscape is a material system, in that condition, relatively unalterable, space is a system of values that changes permanently (SANTOS, 1997).

Before of those foundations, it is noticed that the landscape can be analyzed as the materialization of the social conditions, where they can persist natural elements, although already transfigured. The landscape concept privileges the coexistence of objects and social actions in your economical and cultural manifests, noticing her as a constitution process and rebuilding in ways in your conjugation with the social dynamics (SCHIER, 2003).

\subsection{Environmental Conflicts: Concepts}

The field of the environmental conflicts represents a reality and your study answers to an urgent demand of the definition of actions and interventions in the decisions that determine as a society it satisfies your needs. Like this, to understand the conflicts in the social construction of the reality is important for the group of the society in the formulation of politics that reflect the historical apprenticeship of the social fights of several segments. (LITTLE, 2001)

Now the conflicts are between the national political-institutional space and the world economical space and enter the economical inequality with the political space of the equality. Enormous discrepancies exist in the distribution of wealth in counterpoint to a relative equality of political rights, as for instance, in the electoral system, where each 
person rich or poor is only an autonomous to choose your agents. The emergency of the environmental conflicts happens as the process of economical and social transformation of the territories is deepened, putting in evidence the dispute for hegemony among different conceptions on the form of incorporation of the nature and of the environment to satisfy the communities' material and symbolic needs. In reality of a global world, if the market creates inequalities, the Brazilian State, personified periodically by the elected ones in the electoral process, search controls them or you mitigate them. It is in that dynamics of global local versus and same unequal versus that the western modernity is had. (LITTLE, 2001)

For Little, 2001 the concept of environmental conflicts is: "dispute among derived of the different relationship types social groups that they maintain with yours half natural ", collisions among social groups, in function of your different manners of ecological inter-relationship, with your respective social and natural means.

When it is studied conflicts it is important to remind that the dispute objects are not necessarily just matter and energy, but they also emanate cultural and historical aspects. All the objects and of the atmosphere, the social practices the uses and senses attributed to the they half interact materially and socially for the waters for the soil or atmosphere. It is the appropriation of the resulted world of the relationship among geographical, ecological organization and cultural significance.

With that discussion, she develop for the subject of the territory, that a process of political and economical domain and of appropriation symbolic or cultural of the space for the human groups. (LITTLE, 2001; BASTOS, 2006)

According to Leff, 2001 the societies reproduce for space and ecological processes that they define the culture territory, the society structure, where the social subjects are constituted that they project the geographical space appropriating of him, inhabiting with your significances and practices. According to the author, the territory definition its tells respect a territory system built by practices of appropriation of the world, result of the relationship among geographical, ecological organization and cultural significance.

Haesbaert (2004) it detaches that the territory is characterized by being a process of political-economical domain or of symbolic-cultural appropriation of the space for the human groups by the imaginary and social identification on the space. Raffestin 1993, considers that the space should be understood as previous to the territory, because the territory is characterized by the social relationships and the space presupposes the absence of those aspects. The same author affirms that a territory is a space modified by the work and that reveals power relationships, fundamental for the understanding of the territory in your political character. For that author the territory system can be seen as an individual's attempt or social group of influencing, to control people, resources, phenomena and relationships, delimiting and executing the control on an area. 
Before the exposed, the urban way is part of that dynamics since settles down a net of relationships and disputes of power in the use and territory occupation, be for the administration of the waters, of the soils, of the access to the urban infrastructure among others. Of this point of view, it can be considered the fights for environmental resources as well as you struggle in cultural senses.

\section{Samambaia's stream basin Geographical characterization and your environmental Conflicts.}

Water basin is a geographical unit that is constituted of a space of limited land by the parts more discharges of the relief, with a system of superficial drainage that concentrates your waters on a fluvial system. They are different as your form and it structures, factor that that characterizes your aptitude, potential, limitations and problems. A water basin is structured by your interaction of conditions physical, climatic and topographical of the area and for the socioeconomic and cultural conditions of the population that she shelters. (FAUSTINO, 1996)

Of that it sorts things out, she can be faced as a system who's the interrelations will define the complexity level and the degree of the systems to each other and also the degree of conflict of the different competitive interests in the system. The water basin is, therefore, a soil interaction, water, vegetation that coexists with natural interferences and those of nature. In this system the resources waters serve as indicators of the effects of the unbalance of the interactions of the respective components. For that reason water basins and sub-water basins s they are consolidating as coherent geographical compartments for integrated planning of the use and occupation of the spaces, be rural and urban, tends in view the development sustained in which if o make possible economical activities with environmental quality (SOUZA and FERNANDES, 2000).

The water basin is characterized, then, as a space where the physical system is prefixed to the political system, being this, however, the one that defines that space socially, giving the most appropriate connotation of a territory. Analyzed those foundations, it can understand each other the dynamics of the area of study of the present work better.

Samambaia's stream basin shelters the Samambaia's agricultural colony, whose residents are mainly of middle class, Vicente Pires, where they are the people of higher income, and the Villa São José, composed mainly by less favored people, that join they form the call " Habitation Section Vicente Pires " (Illustration 1). The lands of that basin belong to DF government and Brazilian government. The territory occupancy is still controversy, because the two state organs were not still defined in the part that belongs to each one of him.

The area of the basin is of approximately $20.000 .000 \mathrm{~m}^{2}$ being located in the administrative area of Taguatinga locates in Paranoa's lake water basin, more specifically in "Reecho Fundo" unit and your area of direct influence is delimited to west by the destined area the construction of TAGUAPARK, to south for the 
Taguatinga Highway (EPTG) - DF 085 -, to east for the river Vicente Pires and to north for the Highway Ceilândia (EPCL) - DF 095 - (Saw Structural).

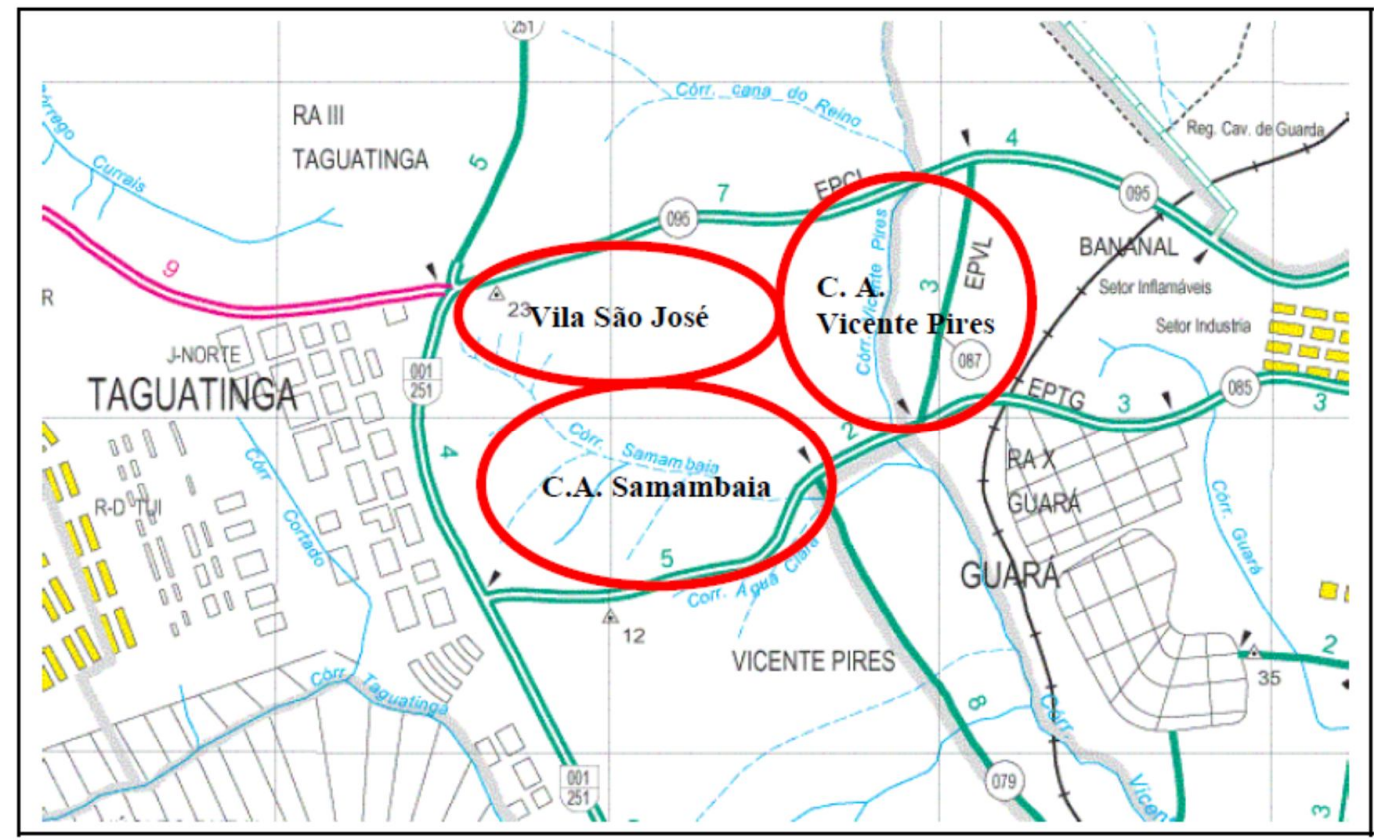

Picture 1: Location of the study area.

Samambaia's stream is tributary of the Vicente Pires river and those two are born and they cross the whole area of the Habitation Section Vicente Pires. Riacho Fund unit, taxpayer of the Paranoá Lake, possesses an area of 228,3 $\mathrm{km}^{2}$ and the extension of your main course is of 13 kilometers, whose principal tributaries of the Riacho Fundo are the rivers Vicente Pires and Guará.

\subsection{Territory Historical Occupation}

The history of the territorial occupation of this basin remounts the decade of 60 where the Juscelino Kubitscheck president stimulated the migration and allocated some farmers' families, among them Japanese, that they lived to the margins of the rivers in the busy areas for Taguatinga, Samambaia and Águas Claras. In the government José Ornelas, in the middle of 1984, an attempt of go out of the area, that stimulated the residents of the area happened they mobilize her being chosen Jorge Cahuí as your speaker before GDF, looking for to solve the problem in a meeting with government authorities in search of an alternative that didn't implicate in the removal of the families of the place. Of that situation the Association of the Rural Producers of the Project Águas Claras appeared - APROAC. The fight of the local population for the maintenance of your permanence in the area took to the creation of the proposal of creation of agricultural colonies staying sweats agrarian vocation.

In 1986, the Government from DF authorized the occupation creating the Project Águas Claras. The Council of Architecture, Urbanization and environment (CAUMA) it 
should previously approve the Project where the rising and division of the area were accomplished by the "Fundação Zoobotânica" of DF (FZDF).

In the middle of the decade of 1980, began, slowly, the process of occupation of those agricultural colonies for houses with urban characteristics that would come to substitute the rural production.

In the decade of 1990, that process of division of the soil was intensified, opportunity in that many people, instead of they accomplish the terms faithfully made a pact in the respective contracts of use concession and use plan, they decided to fraction those public lands and to market them, with own profit, for division into lots ends with urban characteristics without the minimum urban planning.

The fact of the creation of the cities of Guará (1969), Ceilândia (1971), and Samambaia (1985), as satellites it stimulates the idea that Vicente Saucer's area would have the vocation of rural use and it would integrate a " green " belt, that would involve the Pilot Plan and the other urban areas and being rendered to maintain patterns of environmental quality for the water basin of Paranoá.

Though, it was the own appearance of those new cities satellites and your consequent growth, stimulated by the structure of social-space segregation, in the costs and inconveniences of the displacements house-work, and to solve the problems of displacement of the population in direction to the Pilot Plan, they were drifted and built the first subway lines. It was noticed that with that that the idea of the "green " belt was being overcome and it reinforced the tendency of structuring of an urban stain that extends of the Pilot Plan, it goes by Guará, Águas Claras and it arrives Taguatinga, Ceilândia and Samambaia.

\subsection{Samambaia's stream basin Territory use and Occupation}

As important criterion of analysis of the use and territorial occupation of Samambaia's stream basin, the accompaniment was made in temporary scale, in the years of 1964 , 1976, 1981, 1989, 1998 and 2007, the system of the water basin and your area and it was also quantified, in hectares, the use classes and occupation of the territory, to know: the) Ciliary Forest; b) Urban; c) Exposed Soil; d) Cerrado Sensu Strictu; and) Cerrado Field.

The total area of the studied basin is of 1276 hectares. A modification was noticed in the use and territorial occupation along the historical series that were expressed in absolute values and also in percentage. As the presented information are perceptible the changes in the original territorial occupation, of agricultural area for urban. The largest presence of native vegetation of savannah and Ciliary vegetation went being gradually being substituted by exposed soil, by the process of deforestation and division of the original small farms for subsequent urbanization process. With the accompaniment and measurement of the classes of territorial use that process is very perceptible. 
In the quality of facilitating the understanding of the transformation dynamics in the use and territorial occupation in Samambaia's stream basin they were also expressed in percentage, the values found in the present study. The areas of 1964 were compared with the one of the subsequent years, and identifying what increased and what decreases in elapsing of the years in the water basin (Pictures 3 - 6).

In the definition of the cartographic representation, the proposal of structured legend was based in the recommendation of Anjos et alli, 2002:

Forest: They are forest formations that it accompanies the rivers of small load, forming closed corridors. It is during the station it evaporates surrounded by strips of vegetation non forest in the margins;

Urban: To represent the implantation of cities or establishments in the area.

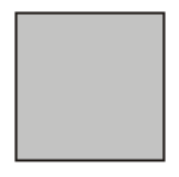

Exposed soil: Consolidation of small farms activities that remove the vegetation of a certain place, exposing the soil to the erosion and changing the landscape in a much larger speed than the natural processes.

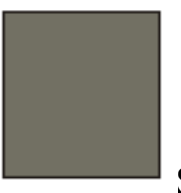

Savannah Sensu Strictu: Vegetation tortuous shaft savânica. Covering about 20 to $30 \%$ and trees on average of 3 meters. It's possesses a stratum herbaceous practically continuous, with degree of covering esteemed in $95 \%$.

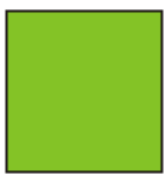

Savannah Camp: Vegetation of larger occurrence in Distrito Federal. Your dossal on average $10 \%$ of covering and height of $3 \mathrm{~m}$ very dispersed, the times it happens high density of herbaceous.

Main roads: Roads drifted by the State for integration of Distrito Federal, as the Taguatinga Highway. 
"m+m+"+"+"'" Secondary roads: Roads without paving (earth highways) used by residents of the area or for access to the small farms and ranches and to places of exploration of sand and gravel.

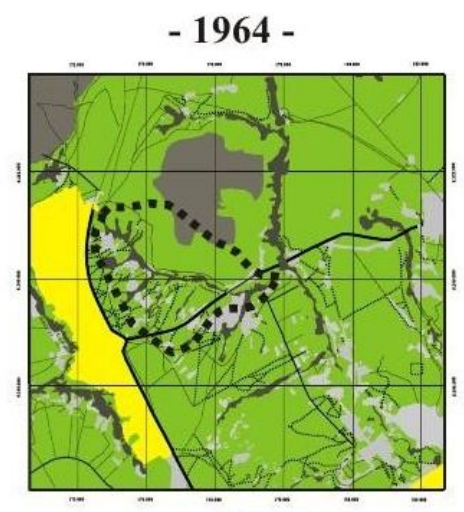

- 1989 -

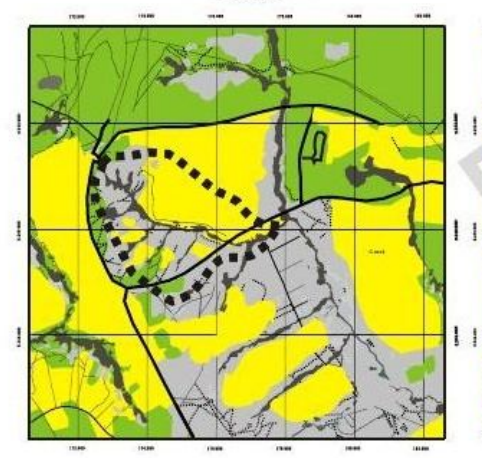

Picture 2 - Accompaniment Multitemporal Water basin Samambaia's stream - 1964, 1976, 1981, 1989,

1998 and 2007.
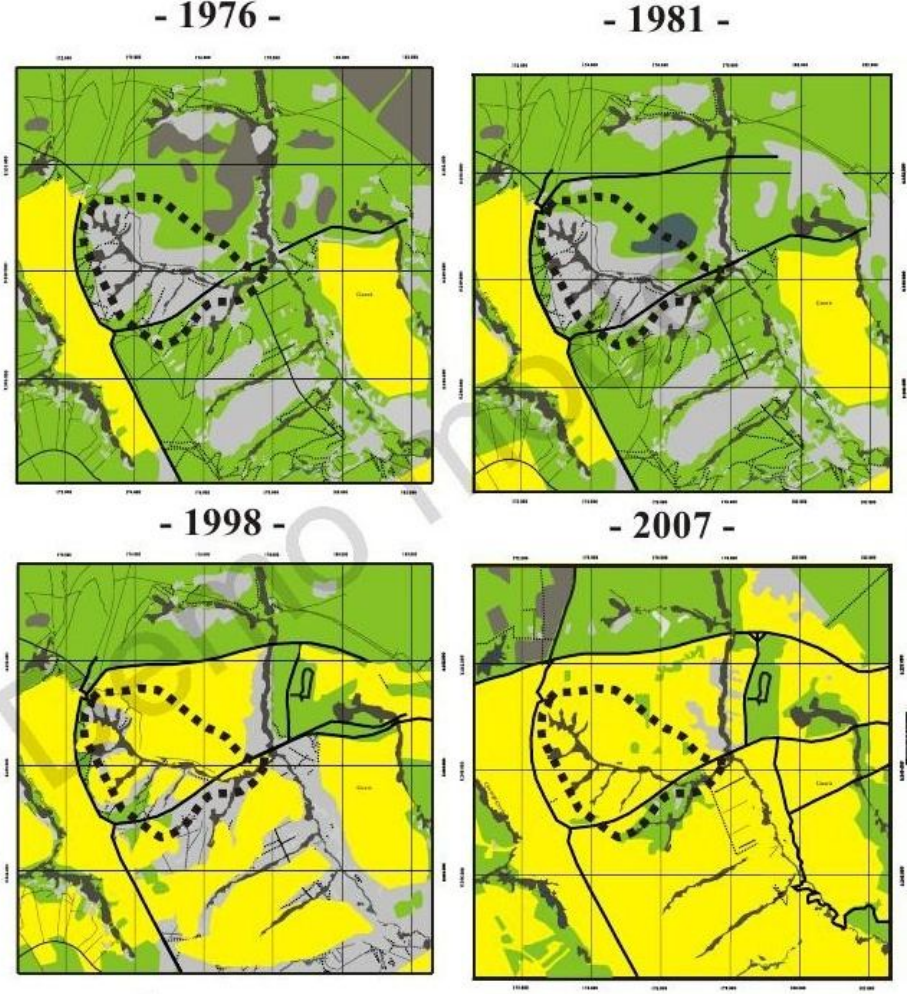

Eletronic Magazine: Time - Technical - Territory, V.3, N.1 (2012), 101:143 ISSN: 2177-4366 


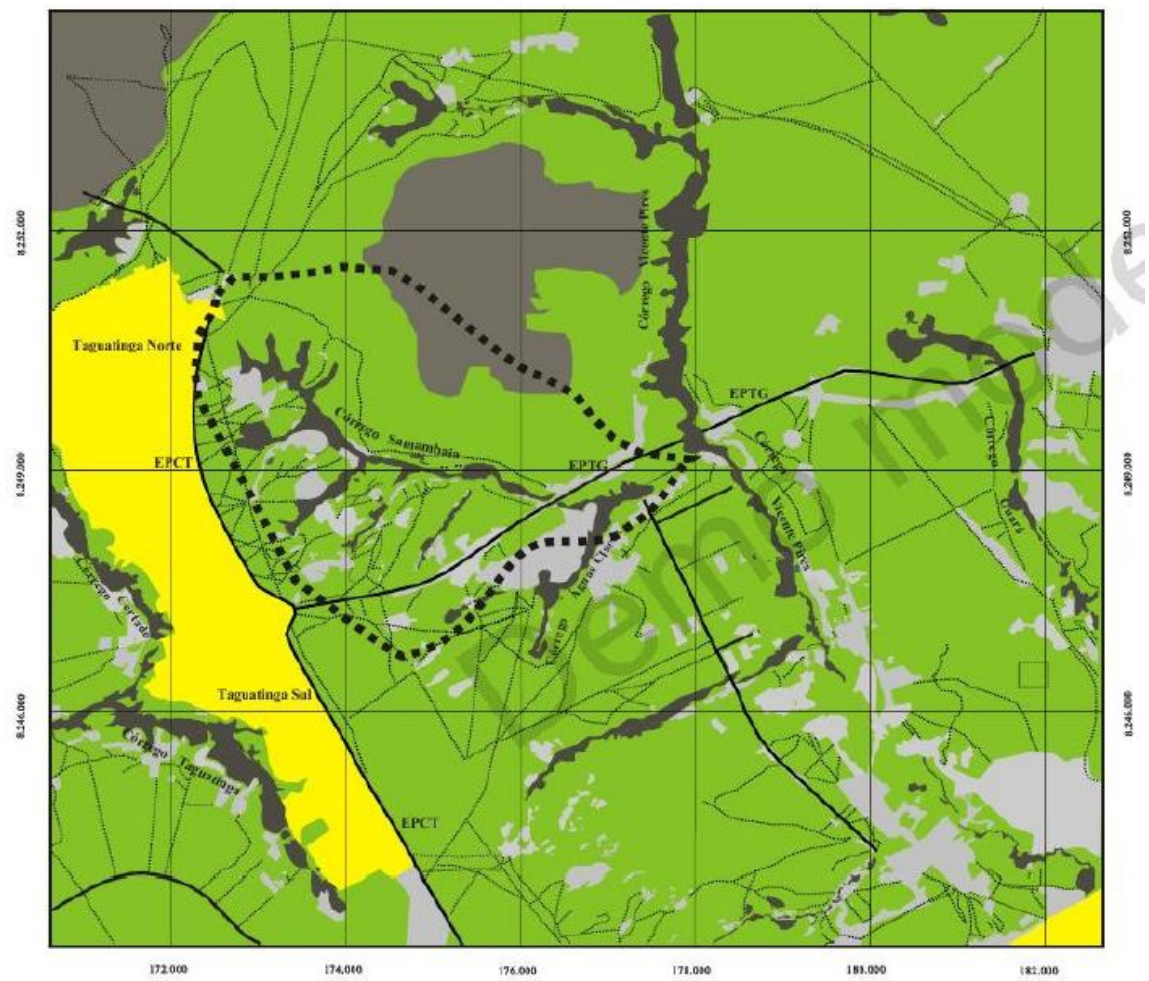

Picture 3 - Accompaniment Multitemporal Water basin Samambaia's stream - 1964.

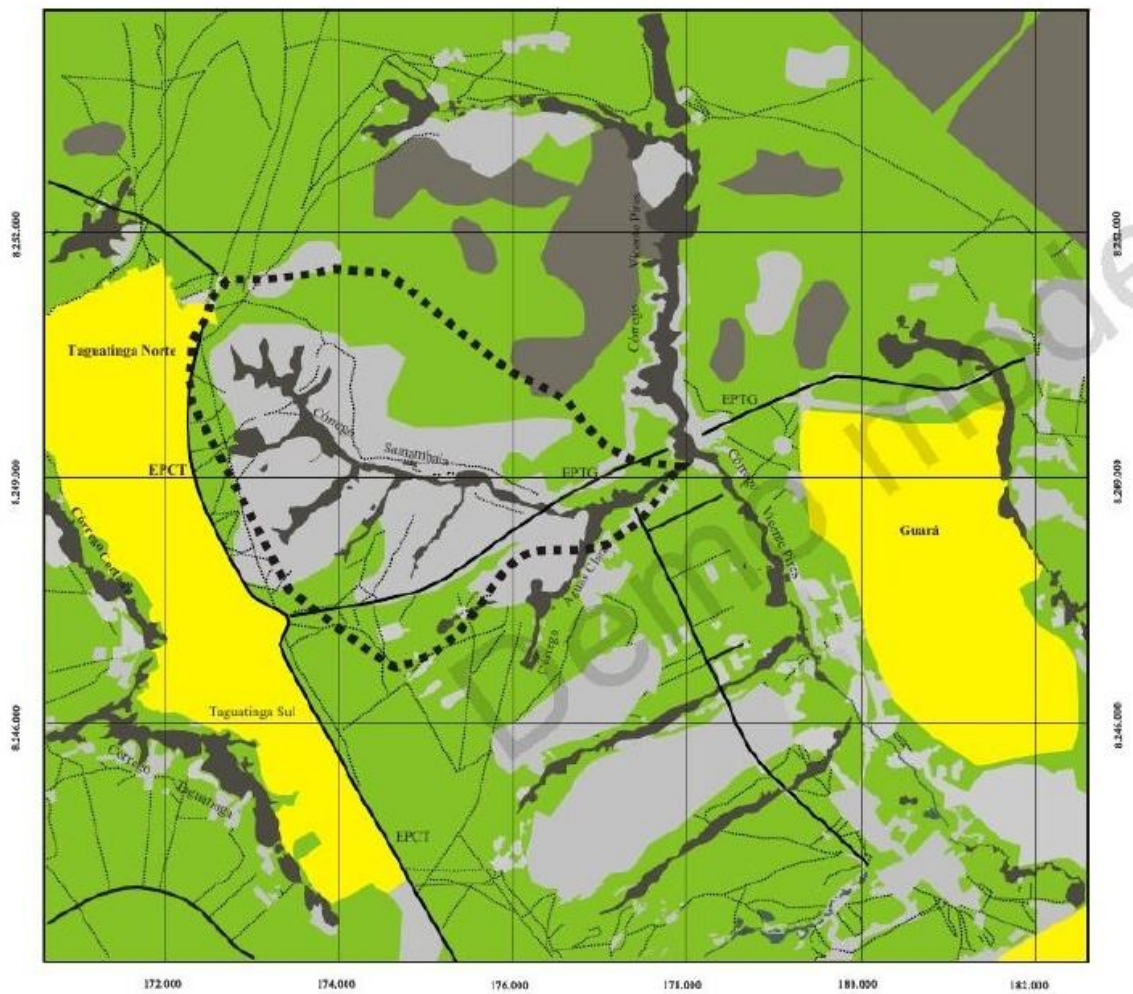

Picture 4 - Accompaniment Multitemporal Water basin do Samambaia's stream - 1976. 


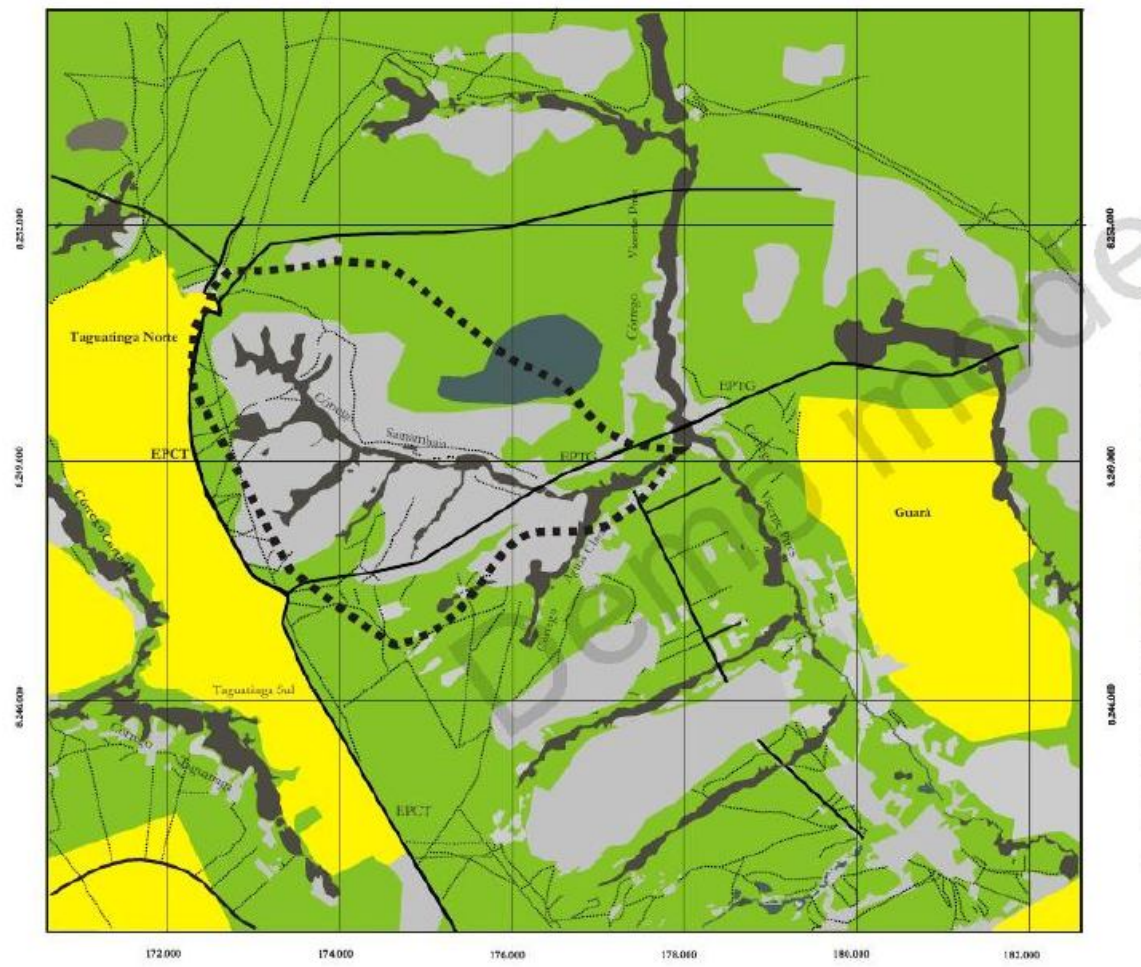

Picture 5 - Accompaniment Multitemporal Water basin Samambaia's stream - 1981 .

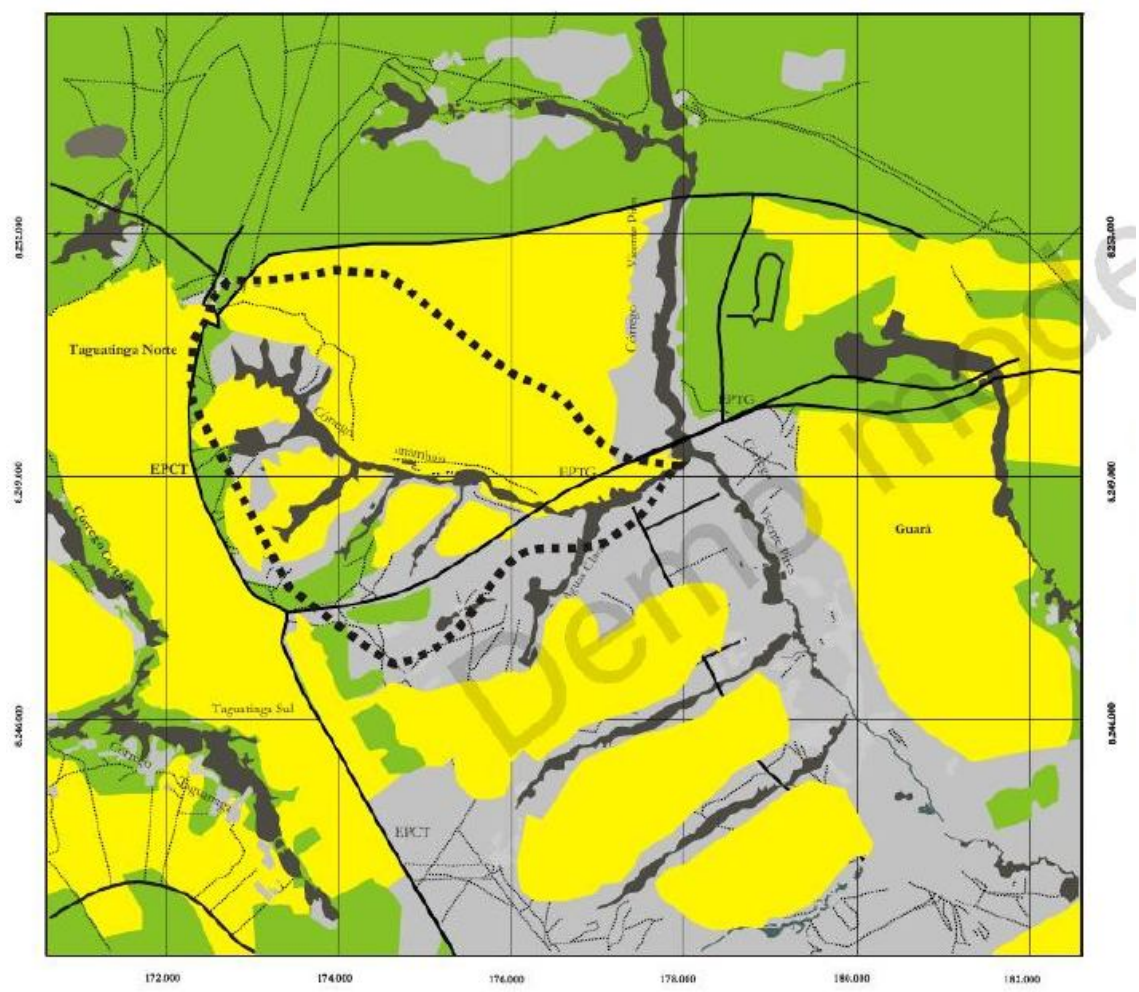

Picture 6 - Accompaniment Multitemporal da Water basin do Samambaia's stream - 1989. 


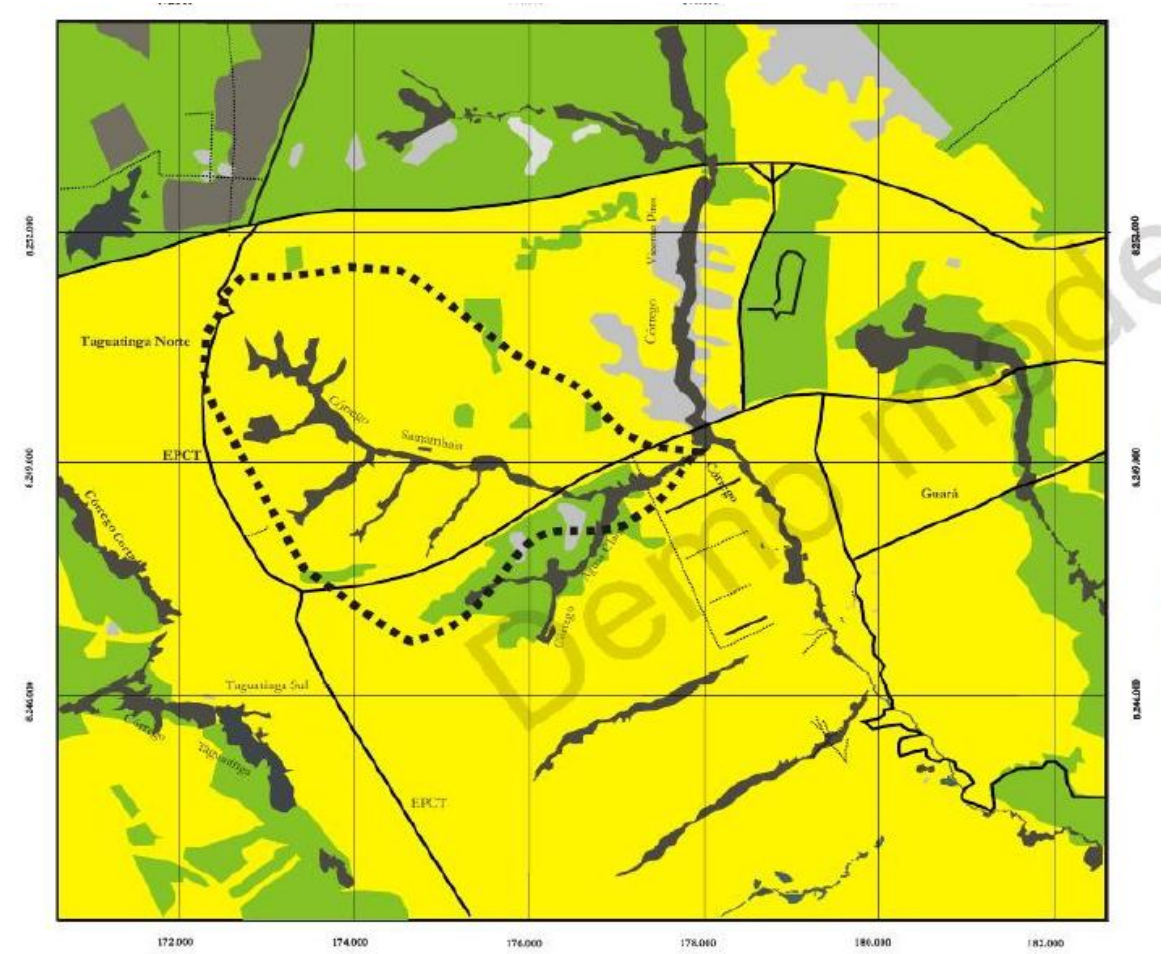

Picture 7 - Accompaniment Multitemporal da Water basin do Samambaia's stream - 2007.

\subsection{Forest Ciliary}

Of the present physiognomies in the water basin the one that fewer suffered modification was the Ciliary forest, and nor for that less intense, reduced in $50 \%$ of 1964 up to 2007. In that physiognomy it is noticed a constant and slow process of reduction of the 174 original hectares in 1964, being reduced for 145 hectares in 1976, 116 hectares in 1981. Starting from 1989 that loss index declines, resulting in an area of 101,5 hectares in 1989 and it is stabilized in 1998 in 87 hectares, value that it stays in 2007.

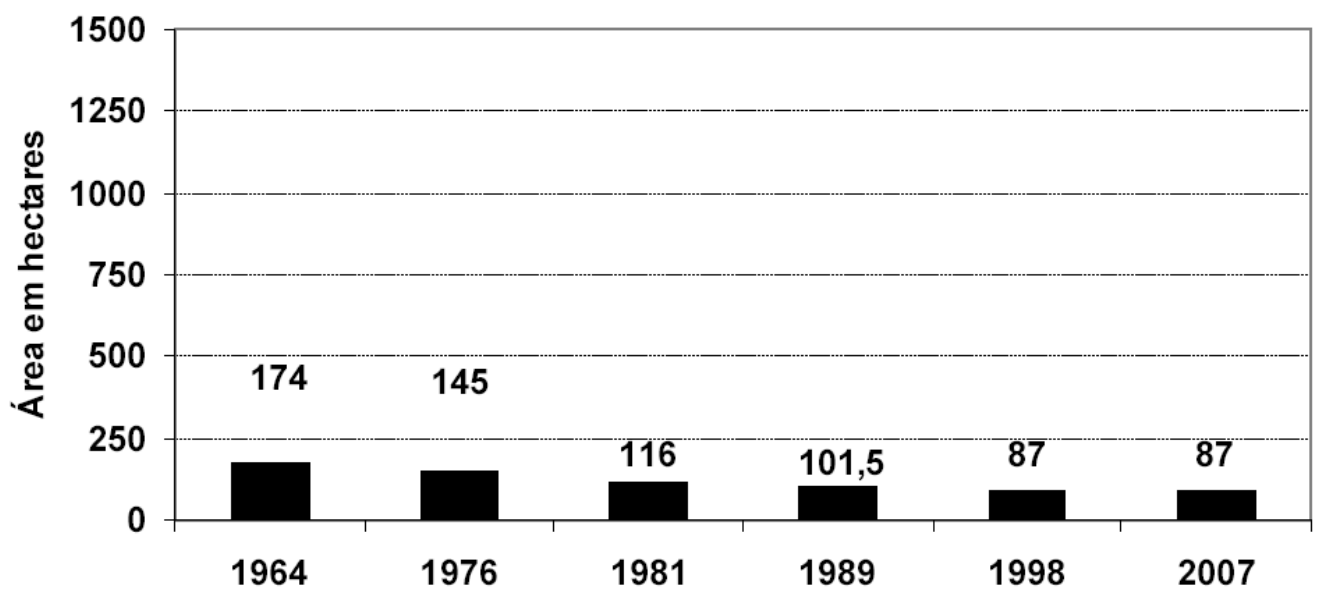

Picture 8 - Accompaniment Multitemporal da Floresta Ciliary na Water basin do Samambaia's stream in ha- 2007. 
The ciliary forest from 1964 to 1976 , had a reduction of $17 \%$ in your extension. In 1981, that reduction was of 33\%, in 1989 the reduction level was of 42\%. In 1998 the ciliary vegetation was of $50 \%$ of the extension found in the first year of the accompaniment, value that stayed up to 2007. Being compared the year of 1964, initial point of the accompaniment, with the current reality of 2007, was possible to accompany the scale of reduction of the ciliary vegetation, that is in the present it dates with a reduction of $50 \%$ of your original extension.

\subsection{Cerrado Field}

In the areas of Cerrado field, the reduction of the physiognomy was larger. In 1964 the extension of the field savannah was of 565,5 hectares with values of 471,25 hectares in 1976 and 449,5 hectares in 1981. Starting from 1989 the reduction of that physiognomy intensifies for values of 275,5 hectares. From 1989 to 1998 that physiognomy maintains the same area extension, to be reduced in 2007 for only 29 hectares, a loss of $95 \%$ of your original formation, in 1964.

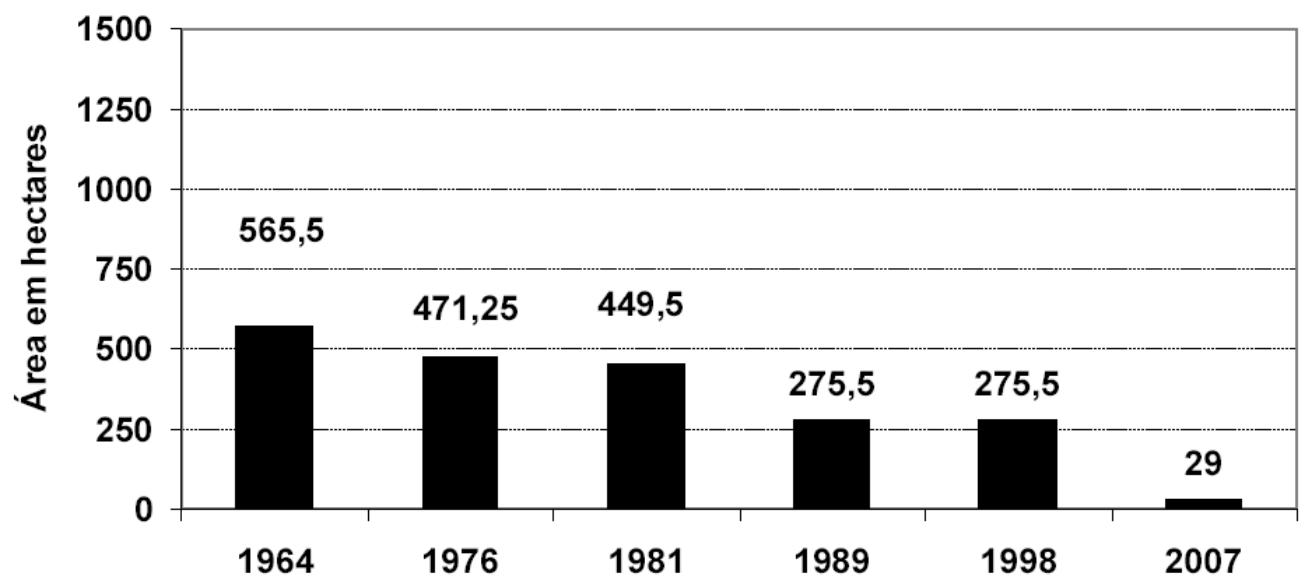

Picture 9 - Accompaniment Multitemporal Cerrado Field na Water basin do Samambaia's stream in ha 2007.

\subsection{Cerrado Sensu Strictu}

The areas of Cerrado Sensu Strictu still suffered more with the intervention in the personal computer-basin. In 1964 your extension was of 290 hectares; was reduced for 188,5 in 1976; 87 in 1981 and between 1981 and 1989 it disappeared of the landscape of the water basin, totaling a reduction of $100 \%$ of your original formation. 


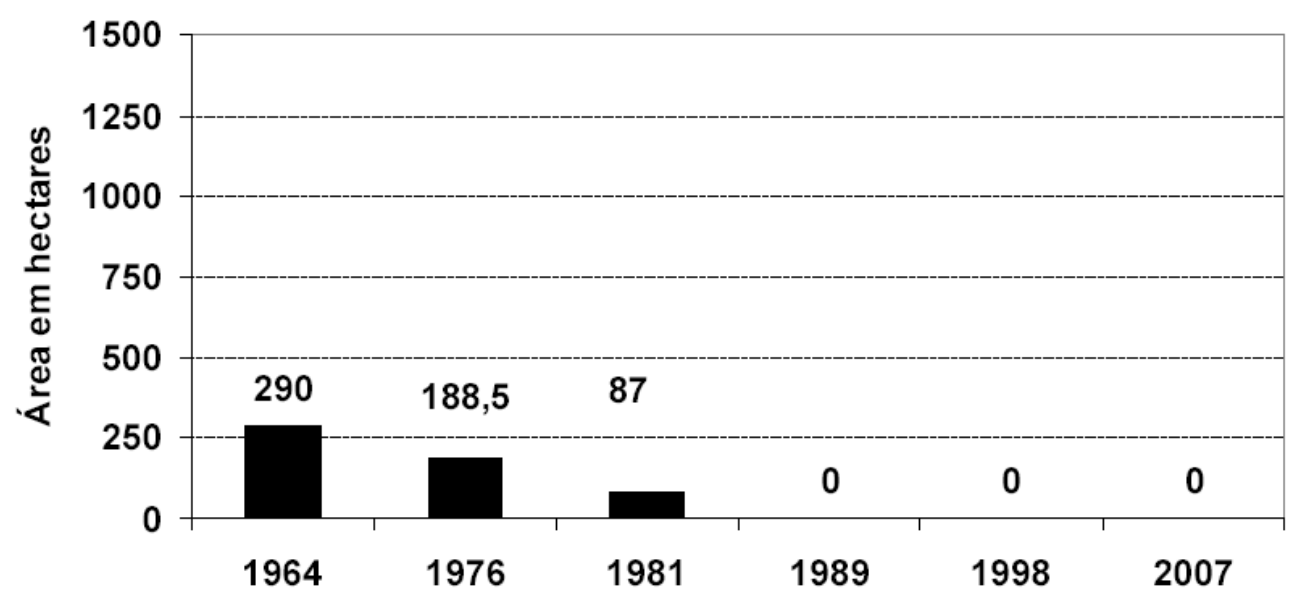

Picture 10 - Accompaniment Multitemporal de Cerrado Stricto na Water basin do Samambaia's stream in ha -2007.

\subsection{Exposed soil}

With the intensification of the territorial occupation, the areas of the call exposed soil had an interesting behavior, in 1964 they were of 166,75 hectares, increasing in 1976 for 391,5 and in 1981 for 543,75. starting from 1989, the area of exposed soil follows a fall path, with values on this year of 384,25 hectares, in 1998 of 398,75 hectares and in 2007 of 29 hectares. And with the beginning of the occupation in the basin the native vegetation was substituted by the areas of exposed soil, mainly for farm administrator's activities. With the coming of the division of the small farms in condominiums, those areas went being substituted by urban occupations, then the explanation that in 2007 one has found the value of 27 hectares for that class.

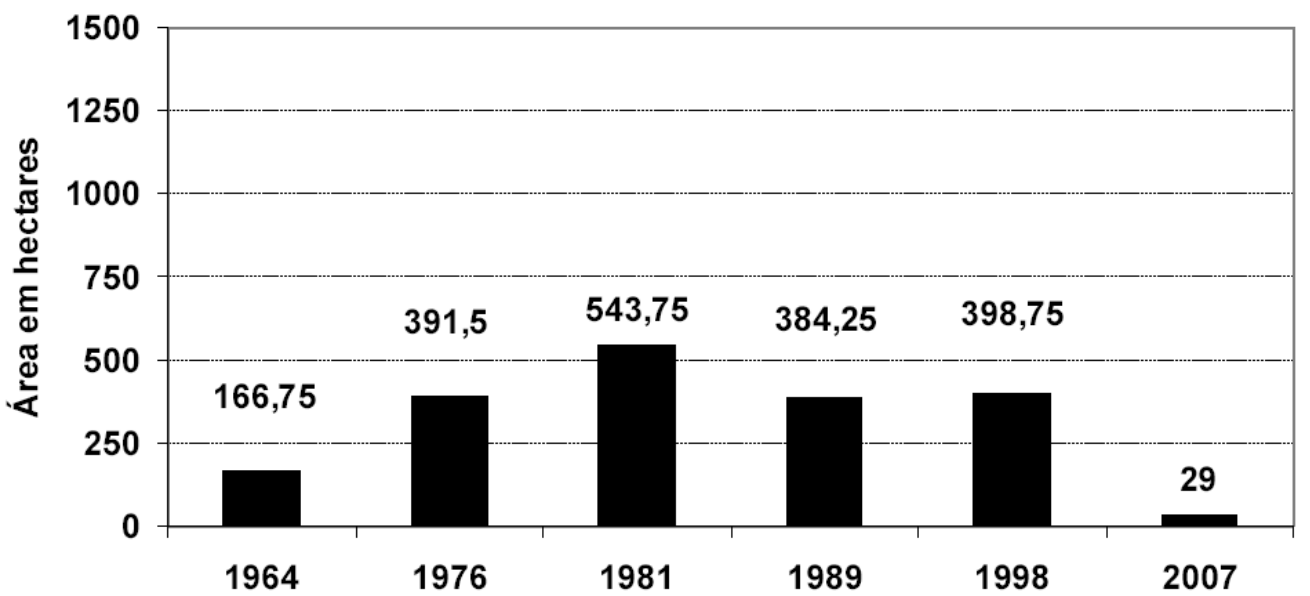

Picture 11 - Accompaniment Multitemporal de Cerrado Stricto na Water basin do Samambaia's stream in ha- 2007.

2.7.

2.8 .

Urban 
In the study of the use and territorial occupation the factor of the urbanization was primordial in Samambaia's stream basin, where the urban expansion can be considered as explosive. Among 1964, 1976 and 1981 the areas with urban occupations were of 79,75 hectares. Between 1989 and 1998 those values increased for 514, 75 and in 2007 values of 1131 hectares, a variation along the historical series of $1318 \%$.

The growth of the urban in the basin, shows as well as it is it was busy and modified without minimum criteria of maintainable nor obedience to the existent legal instruments. In 1964, 1976 and 1981 the urban area followed with 79,75 hectares. Between 1981 and 1989, the values increase drastically, being in 1989 of 514, 75 hectares, in 1998, also of 514, 75 and in 2007 with the high value of 1131 hectares.

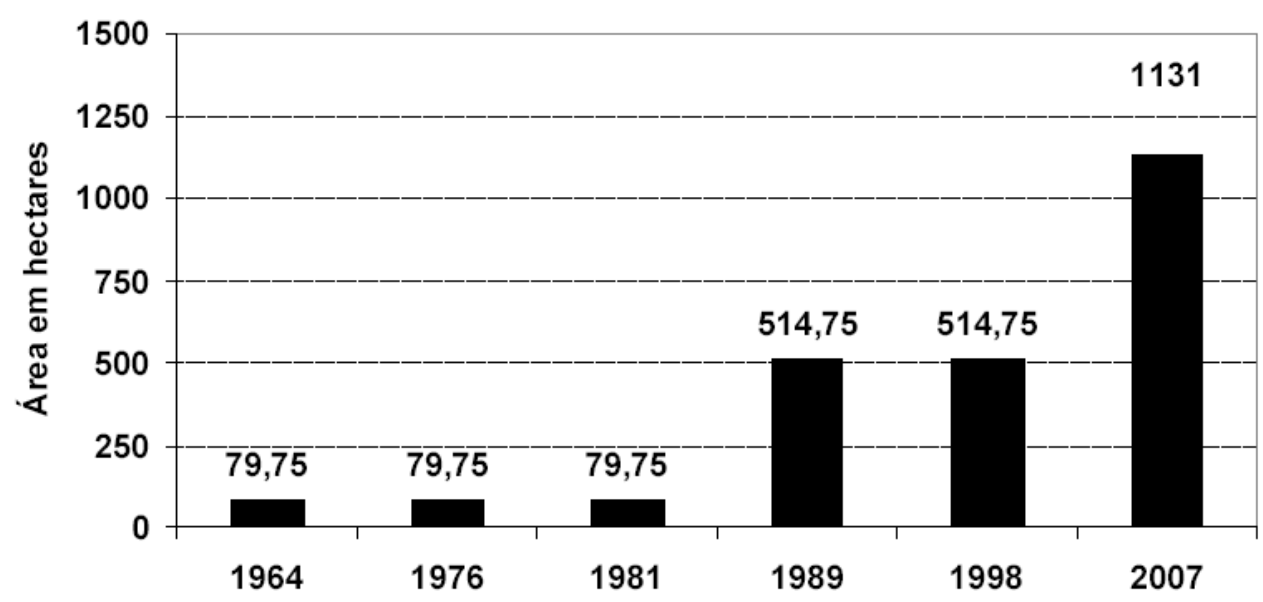

Picture 12 - Accompaniment Multitemporal de Cerrado Stricto na Water basin do Samambaia's stream in ha -2007 .

A Synthesis of the Socioeconomic Profile of the Inhabitants of Samambaia's stream basin.

Collaborating in the understanding of the dynamics of the environmental conflicts in Samambaia's stream basin, Maciel, (2001) in your master's degree dissertation it developed a field research looking for to know the residents' of Samambaia's stream basin socioeconomic profile and also to know that means for those people to live at that place. In your work the basin was it divides at small farms fractional and not fractional (remaining farm administrators). A synthesis of the author's results will be here presented, in way to collaborate in the understanding of the use and territorial occupation of Samambaia's stream basin.

An interesting initial die that of the hundred and thirteen properties studied by the author (parceled out and not parceled out), thirteen only carry out agricultural activities, while a hundred exercise other activities. Specifying the result, among the occupations, twenty percent corresponds to merchants, twenty percent to public employees, eleven percent to farmers, nine percent to entrepreneurs, eight percent to commercial employees, four percent to housewives, and nine percent to several urban professions as: bank, lawyer, commercial representative, keeper, driver, among others. This 
composition proves the change of the area your second original purpose since the agricultural activity, with eleven percent, it is surrounded typically by activities urban, corresponding to 89 percent of the remaining of the place. (MACIEL, 2001)

With relationship at the level of income of the population in the place, it is compatible with the one of the middle class of DF. This can be proven for the sampling that demonstrates that forty six families have revenue above ten minimum wages and twenty families, among six to ten wages, what results in a total of fifty nine percent of the sample. In the item education there is a profile differential that appears for the significant change in the years of study, prevailing at the place a population of larger educational level. While the remaining farm administrators obtained the percentile of seventeen percent of teaching superior level, the population that lives at parceled out small farms it reached sixty six percent. (MACIEL, 2001)

On the interviewed people's origin, there was the prevalence Center-west with the interviewees' of the sample forty percent, followed in the proportion of twenty-seven percent for the Southeast area, twenty-five percent for the Northeast area, five percent for the area percent for the North area. (MACIEL, 2001)

Confirming the fort process of territorial transformation that acts in the water basin becomes interesting the information obtained by the author that the farm administrators remainder interviewees fifty nine percent received among the years two thousand and two thousand and a, the purchase proposal of real estate, what demonstrates the constant blockade on the part of companies, indicating an imminent adhesion risk to the division. (MACIEL, 2001)

In what refers to the reasons in moving to the place, sixty seven percent of the samples, made for subjects related to the access easiness the home, conjugated to the aspect of peacefulness and larger space. Completing the percentile ones, twenty-four percent moved because of employment and the agricultural activity contributed with only nine percent, as motivator to reside at the place. Those information base on the gradual process of mobility of the resident middle class in the Pilot Plan and in administrative areas, like Guará and Taguatinga, for other residential areas in DF, configuring the reproduction of a life model in the terms of a class referential that light in consideration aspects as:

" size of lots;

" location;

house " style;

architecture " project;

" safety of the place. 
All those choice criteria are symbolic elements they extol the effectiveness of that space as a model or a lifestyle, where she look for to accomplish an ideal of home of better quality and still to enjoy of the proximity of the center of the capital of the country. (MACIEL, 2001)

In compensation, although the factors peacefulness and larger space were mentioned as some of the reasons of if they change for Samambaia's stream area, the item peacefulness is in opposition to the factor safety that was mentioned thoroughly among the lacks in the place. In that way, it is observed that in the course of time, consolidates a new neighborhood, of attractive purchasing power, and appearing the other common problems the other Administrative Areas of DF. (MACIEL, 2001)

Analyzing the subject of the year in that there was the change to the place, the information obtained by the author they show that the process was more accentuated between thousand nine hundred and ninety and one to two thousand, when sixty six percent of the changes happened. These data are corroborated by data obtained in the accompaniment Multitemporal developed in the present work that show the space evolution. That time understands to the period of larger expansion of the denominated condominiums, when more than 80 thousand lots were distributed, busy or sold, being almost whole in establishments. (MACIEL, 2001)

That process intensified with the approval of PDOT/97 and PDL of Taguatinga that it legitimated the busy areas, altering the defined macro-zoning in PDOT/92. this way, it allowed the occupation with diversified uses and it introduced the concept of use.

With relationship to the farm administrators remaining interviewees, that are fifteen percent of the sample worked by the author, it was appeared that eighty eight percent of them still conserve the small farms in your original form, without division. It is worth to point out that fifty nine percent of them received sale proposal between 2000 and 2001, time of development of the research, being fifty five of those proposals of real estate. (MACIEL, 2001)

The change process is noticed that the author shows, since of the existent remaining small farms only eleven percent wants to increase the production, in spite of fifty eight percent of them not to have commercialization problems and fifty three percent think the investments compensate. Such data prove that the agricultural activity is giving up space and giving place to the divisions and the disordered urban expansion. (MACIEL, 2001)

Analyzing the subject of the water, it was observed that a concern of the residents doesn't exist with the readiness of the springs of provisioning, be superficial, be underground; to the remaining farm administrators, only six percent is provisioned of the water of Rio to irrigate the production. Of the total interviewee, ninety four percent has as source of provisioning the artesian well for the consumption domiciliary, although sixty six percent thinks the water is not appropriate for the consumption. (MACIEL, 2001) 


\subsection{An Expansion Axis}

Before what it was presented, it is noticed that the connection axis among Taguatinga, Ceilândia and Pilot Plan is without a doubt an axis of urban growth, for if they treat of the largest poles of attraction of DF. The opening of roads like EPCL (Highway Ceilândia), the acquaintance Structural Road or still DF-095 with your 12,6 km of extension; it is the north boundary of Samambaia's stream basin; EPVL (Highway is Worth or DF-087) that ties the Structural to EPTG going by the Jockey and EPVP (Highway Vicente Pires or DF-079), that it links EPTG to the Highway Núcleo Bandeirante, they still contributed more to the occupation of that place, whose original vocation was the rural activity.

The fact is that that growth is structured by a middle term, where moves the landscape of rural for urban, but not totally. Urban zone is the area characterized by the continuous construction and the existence of equipments destined social ace basic urban functions, as house, work, recreation and circulation.

Being followed that thought line, the area of Samambaia's stream basin is not characterized for fully urban, due to the infrastructure lack and of appropriate urban equipments to the human occupation, generating with itself several environmental problems. Still has the subject lander, since the residents of that area are not owners of the lands, because the same ones belong to the Union and GDF, and not even the government knows which leaves it belongs to who. That whole uncertainty climate, generates a lot of anxiety on the part of the residents and countless conflicts. The occupations of areas of larger environmental are susceptible to eradication operations, fomenting the animosity between the residents and the Brazilian State.

The area of Samambaia's stream basin, same being considered as remaining rural area, it is today an area of urban expansion, needing that your divisions into lots are approved for the competent organs, destined to the house, to the industry or the trade, even if located out of the defined zones in those terms, since the occupation is made and all those people's retreat in the area would stimulate a true war climate in the area.

An urban planning structured in functional section of the activities that they were accompanied of restrictive rules of use and occupation of the soil with the adoption of punctual solutions to solve the problems of long date, it generated impasses in the government action that, - in a picture of habitation demands, on the part of certain social segments not assisted, - they ended for stimulating the irregularity of the occupation.

\subsection{Identified interventions in Samambaia's stream basin}

It is important to point out that the proposal is to identify interventions in the basin and not to be a study of environmental impact that is something wider and complex. The definition and characterization of the interventions are important, because your analysis 
can address the distribution of new constructions of the enterprise, besides proposing alternatives that minimize or eliminate the individual impacts and your association.

\subsection{Samambaia's stream basin as Stage of an environmental Conflict}

It is unanswerable that today, Samambaia's stream basin is a litigation area, where the several involved actors are in constant it knocks, in the maintenance of your interests. The government's from DF actions are still shy, before the problem and for that it is noticed, it will be again made the politics to legalize of the irreversible, ratifying the model of administration of the territory in vogue in DF.

In general lines the analysis of the environmental conflict follows the following structure.

Being analyzed that head office can be outstanding some important points in that actors' identification. The residents can be divided in categories, that would be the:

1) lessees: Important actors in the division process, motivated by the financial aspect, they tried to guarantee the compensation in advance on the improvements accomplished in your place. They are natural persons that received from GDF, the concession for use of the earth, for ends of agricultural production, to put periods from thirty to fifty years. These didn't have the definitive deed of the earth that still belongs to the government distrital. In the case of dispossession, the lessees would receive compensation for the improvements accomplished at the small farm. However, there was the possibility of transfer of this ownership right the third, which would take the same responsibilities, close to GDF. It is worth to point out that the lessees were not entitled of fractioning the places nor of transforming them in condominium. However several lessees give in to the speculators' pressures and they authorize the division of your places in smaller lots.

2) buyers: They become separated among the one of economical and social interest. Some sought in the division of the basin the warranty of the right to the home and there are also the ones that they acted in the slope of the real estate speculation. They are natural persons, in your great majority of middle class that shimmered in the irregular division of the agricultural colonies Samambaia, Vicente Pires and Villa São José, Águas Claras the possibility to solve your demand for habitation comfort. The buyers can be classified in four different groups:

a) rent Residents - The lack of homes and of government programs to assist the demand of the population forces the individual to look for habitation autonomy;

b) Residents in immobile own - they Sought a middle to assist the demand for comfort. They see in the lots the possibility to build more comfortable houses;

c) Residents in immobile own financed - The current politics of the Habitation Financial System is provoking a high payment lack index on the part of the unit holders that don't get to honor the signed contracts. The irregular divisions are option to balance the family budget. 
d) real estate Speculators - they Take advantage of the articulation of the informal market, with the purpose of obtaining won futures. Also buildings and houses for us to rent.

e) "grileiros" (salesperson of irregular earth): These totally possess an interest financial, breaking up with all the legal limits to implant condominiums. They usually disappear leaving under the responsibility of the buyers all the responsibility for the made infractions. They are agents of great force in the process of territorial transformation, mainly in your initial phase. Your strategy is to exercise strong pressure on the lessees, buying lots, parceling out them, marketing them and disappearing of scene.

4) the politicians oscillate between the social concern and the personal interest of projection seeking the elections, since they happened proposed and promises that usually after the election they are not accomplished. The parliamentarians' involvement in the subjects lander is a reality, mainly in what concerns to legalize. Several candidates made promises of legalization of the divisions, besides candidates to the government of the state. To legalize promise and infrastructure implantation still stimulated more the search for lots and the proliferation of the condominiums. Many political they have been showing if interested in solving the problem, perhaps thinking about the quantitative of involved families. On May 21, 2003 Assents Land's Commission - CAF of the Legislative Camera approved bill that foresees the direct sale of lands in irregular divisions into lots to the occupants. That is one more indicative of the political involvement in the subject.

5) the public prosecution service that acts not only in that basin, but also in the whole DF in the attempt of to restraint the irregular division and to punish the responsible evoking the beginning of the juridical legality for the to legalize lander and in the environmental defense. Your action dashes in constant preliminary in favor of the occupants of constructions in areas of permanent preservation, even with the validity of the forest code. MPDFT defends the auction as the middle of regulation of the condominiums.

However it is clearly considerable the amount of situations contrary to the environment and to the collective interests in those places that it joins the auction processes. The public prosecution service is cleaning subjects in DF and preceding the investigation of several accusations.

With relationship to the government from DF, that actor's performance can be analyzed under different optics. One of them would be the social. will arrive the moment in that GDF will have to act in an effective way with relationship to the irregular occupations, since thousands of families reside in those lots and waits of the government a positioning with relationship to the legalization lander. Another would be the economical because that irregularity situation causes damages to the treasury, since the government doesn't receive for the sale of the earth and it doesn't also collect anything with imposed like IPTU. The politician since the omission game and promises of to legalize lander can be used as instruments of political handling in electoral periods. The 
organs directly involved they are: the environment Clerkship - SEDUMA - Public Safety's Clerkship, through SUDESA, CAESB, CEB with the infrastructure and TERRACAP, responsible for the administration of the public lands belonging to GDF. TERRACAP defends and it is applying the auction process to regularize the irregular condominiums. The governor supports the posture of the company, though it is giving signs that can alter the model, in case he finds legal back-up. The Government from DF didn't get to inhibit the proliferation of the divisions and now it doesn't get to establish a model that makes possible the control and the fiscalization of the public lands.

"grileiros" (salesperson of irregular earth): These totally possess an interest financial, breaking up with all the legal limits to implant condominiums. They usually disappear leaving under the responsibility of the buyers all the responsibility for the made infractions. They are agents of great force in the process of territorial transformation, mainly in your initial phase. Your strategy is to exercise strong pressure on the lessees, buying places, parceling out them, marketing them and disappearing of scene.

The politicians oscillate between the social concern and the personal interest of projection seeking the elections, since they happened proposed and promises that usually after the election they are not accomplished. The parliamentarians' involvement in the subject's landers is a reality, mainly in what concerns to legalize. Several candidates made promises of legalization of the divisions, besides candidates to the government of the state. To legalize promise and infrastructure implantation still stimulated more the search for lots and the proliferation of the condominiums. Many political they have been showing if interested in solving the problem, perhaps thinking about the quantitative of involved families. On May 21, 2003 Assents Land's Commission - CAF of the Legislative Camera approved bill that foresees the direct sale of lands in irregular divisions into lots to the occupants. That is one more indicative of the political involvement in the subject.

5) the public prosecution service that acts not only in that basin, but also in the whole $\mathrm{DF}$ in the attempt of to restraint the irregular division and to punish the responsible evoking the beginning of the juridical legality for the to legalize lander and in the environmental defense. Your action dashes in constant preliminary in favor of the occupants of constructions in areas of permanent preservation, even with the validity of the forest code. MPDFT defends the auction as the middle of regulation of the condominiums.

However it is clearly considerable the amount of situations contrary to the environment and to the collective interests in those places that it joins the auction processes. The public prosecution service is cleaning "grilagem" subjects in DF and preceding the investigation of several accusations.

6) with relationship to the government from DF, that actor's performance can be analyzed under different optics. One of them would be the social. will arrive the moment in that GDF will have to act in an effective way with relationship to the irregular occupations, since thousands of families reside in those lots and waits of the 
government a positioning with relationship to the legalization lander. Another would be the economical because that irregularity situation causes damages to the treasury, since the government doesn't receive for the sale of the earth and it doesn't also collect anything with imposed like IPTU. The politician since the omission game and promises of to legalize lander can be used as instruments of political handling in electoral periods. The organs directly involved they are: the environment Clerkship - SEDUMA - Public Safety's Clerkship, through SUDESA, CAESB, CEB with the infrastructure and TERRACAP, responsible for the administration of the public lands belonging to GDF. TERRACAP defends and it is applying the auction process to regularize the irregular condominiums. The governor supports the posture of the company, though it is giving signs that can alter the model, in case he finds legal back-up. The Government from DF didn't get to inhibit the proliferation of the divisions and now it doesn't get to establish a model that makes possible the control and the fiscalization of the public lands.

The federal government through IBAMA and of SPU. The first has the focus in the environmental protection of the areas of permanent preservation. The environmental licensing that is granted by that organ and the infrastructure works it will only be able to be initiating with the eradication of the constructions in areas of permanent preservation, the fuse of the conflict. It is also noticed that the political position different from the government distrital and federal it uses the subject of the eradications as tool for political-supporting disputes. SPU has it interests mainly in the social subject and lander, since it is linked to the ministry of the cities, that has projects of legalization lander of urban occupations in the whole country. It leaves of the busy lands in the basin it belongs to the Union. SPU was placed favorable to legalize and it presented a legalization proposal, but it is displeasing integral of other parts of the federal government, as well as the Civil House of the Presidency of the Republic. understands each other that such restrictions are of political character, once the polarization in DF is very intransigent.

\section{The Conflict historical}

For treating of a consolidated urban occupation and that didn't go by the stages of the environmental licensing nor of urban plan, does it fit to point out that the occupants of the basin are making the inverse process to get to legalize of your area. Now takes place the stages that would be previous the purchase of the lands: environmental licensing, installation license (approval of the project ) and operation license. For so much it was demanded the order of a Study and Report of Environmental Impact - EIA/Rima that made a diagnosis of the occupation, pointing the damages and the threats to the environment. The document also defines the limits of residential expansion of the area and it recommends measures of environmental compensation and it is under evaluation of IBAMA and SEDUMA, could approve entirely, to approve with to condemn the habitation section.

The most acceptable is that it is approved, or approved with provisos, and the community, based on that opinion makes a plan of adjustment of the occupation, 
proving that the damages will be healed. That plan is submitted to the process of obtaining of the three licenses: previous environmental license, installation license and operation license. In that case, the urban infrastructure would not be built, but adapted.

Before the challenge of to legalize lander of that place, several initiatives were taken. In June of 2005, IBAMA, GDF, residents and Clerkship of Patrimony of the Union - SPU, linked to the Ministry of the Planning, they agreement aiming at to legalize. The largest fetter to that process the prohibition of new constructions. Another Group of Work - GT was constituted to regularize the rural areas, busy with precarious lease contracts. Those lands would be sold through public auction by TERRACAP. However the Company of Technical Attendance and Rural Extension of DF - EMATER protested of the decision alleging that the impact generated by the auction of irregular rural lots in DF it would be immeasurable, what deflagrated an insecurity wave and judicial disputes. (CARVALHO JÚNIOR, 2007)

Looking for to outline the situation, in September of 2005, the then governor of DF Joaquim Roriz by ordinance that allowed the auction of lots in rural area where the situation lander is not under decision of the justice and that possessed territorial planning (extremely rare cases). Such measured it also generated the insecurity among the rural proprietors, since many alleged, the time, the possibility to lose the land for third, once the auction prioritizes the buyer that to offer the largest financial amount for the land. In the same time, the Commission of Constitution and Justice of the Federal Senate they approved a bill that allowed the cession of the lands that belonged in areas of the Union, case of the Agricultural Colony Vicente Pires, but being left out Agricultural Colony Samambaia and Villa São José, that are in areas of GDF.

In that to legalize attempt, the evaluation of the land would be calculated without the improvements; the sale could be parceled out, with the payment of a sign of $10 \%$ and the remaining divided in up to 120 months; after the purchase, the resident is forbidden of selling the property for 05 years; the resources obtained by the direct sale they would be destined to the construction of popular homes; the occupant could only buy an only lot; and, finally, the resident should prove it executes occupation of the land there is, at least, 05 years of the date of publication of the law. It is worth to point out that, of the practical point of view nothing happened until the present moment. (CARVALHO JÚNIOR, 2007)

Also in September of 2005 a Term of Adjustment of Conduct was firm - TAC with views to the liberation of the environmental licensing for implantation of the nets of water and sewer in the area that includes the Agricultural Colonies Samambaia, Vicente Pires, and Villa São José, belonging to the same geographical area. In agreement with TAC, two promoters of the Federal public prosecution service - MPF would fiscalize the execution of the agreement, signed among IBAMA, CAESB, Agency of Water and Sanitation - ADASA, Clerkship of Coordination of the Regional Administrations SUCAR, environment Clerkship and Resources Waters - SEMARH, Integrated System 
of Surveillance, Preservation and Conservation of Springs - SIVÁGUA, besides Public Safety's Clerkship - SSP.

To the SIV-Água the task would fit of lifting the Areas of Permanent Preservation APP of the area and to present a report on the limits of the same ones, besides the constructions and constructions of the area. CAESB would take charge of demarcating the areas of pointed APP for the SIV-WATER. SEMARH would fiscalize those stages, elaborating reports that would be given periodically to IBAMA.

After that stage, the SIV-WATER would coordinate operations of eradication of erect constructions in APP in the period of, at the most, one year after the signature of TAC, being that demolition one of the demands for emission of the installation license for the section. All the entities should to impede, continually, new invasions and constructions. Still according to TAC, after the demolitions, there would be a reforestation of the area with the planting of seedlings. In April of 2006, the SIV-Água concluded the demarcation of the residences that were in APP, besides the rising of all the constructions that should be demolished. In July of 2006, IBAMA began the notifications for the residents of those residences built illegally in APP to abandon the properties.

In July of 2006, the General Attorney's office of DF - PGR recommended IBAMA the suspension of TAC, alleging that GDF would not accomplish the activities, or either the awake calendar in TAC. IBAMA then gave period of five days so that GDF presented new action plan of having dropped for the constructions in APP, otherwise, it would suspend the license for installation of the net of water. Until the end of the month of July of 2006, only 12 constructions had been dropped indeed.

Arguing that it would not really get to accomplish the established goals in TAC, the SIV-WATER requested a larger period to execute them dropped of residences in APP. However, the period of five days, stipulated by IBAMA it expired and the works of construction of water and sewers in the Agricultural Colony Vicente Pires were suspended, tends in view that GDF didn't execute activities and periods in TAC. In spite of the suspension and, without any answer of IBAMA, in September of 2006, GDF elaborated new action plan of having dropped, month in that TAC indeed would expire and the works of CAESB in the Agricultural Colonies Vicente Pires, Samambaia and Villa São José.

Several the factors that influenced the slowness of the process of operations of eradication of constructions were, necessary for the environmental licensing of the works. The countless ones preliminary granted to the residents, prohibiting to the actions of dropped on located houses in APP, the intense period of rains, and the terrible administration, human and administrative, on the part of GDF in accomplishing TAC, besides the traumatic and difficult process of eradication of inhabited constructions. The ideal would have to be avoided, but after having structured, the removal of those families is extremely difficult. A lot it is criticized organs as the extinct Siv-Água or now SUDESA, however only who the daily lived of eye to work in the eye with 
residents understands what is to be in that ingrate occupation and understands the real meaning and consequences of the Brazilian State omission.

The discussion concerning the modality of sale of the lots is source of immeasurable discussions. Residents alleged that the auction would promote the speculation and that them, to the they buy the lots, they acted of good-faith tends, therefore, the right preferably in the purchase. On the other hand, TERRACAP affirms to be the landlady of the lands and, being state, your goods can only be sold in the auction form, in agreement with the law 8.666/93 - Law of Auctions and Contracts. In January of 2006, a commission created by GDF, constituted by representatives of TERRACAP, Company of Environmental Sanitation - CAESB, Energy Company of Brasília - CEB, Clerkship of Urban Development and House - SEDUH, General Attorney's office of DF - PGR, besides 05 integral of the Movement to Live Legal, they met in the attempt of directing solutions for the to legalize lander through the law of auctions and contracts. The largest prominence for the subject, is only point of consent of the commission it was that, for the irregular condominiums, it could be applied the Law 8.025/90, once, in your article 6th there is an exception. Such exception consists of granting to the current occupants preferably the right before the publication of a competition proclamation. There is still the period of 30 days for the current occupants to manifest interest or not in acquiring the good. The strongest argument, however, based on the allegation that that model was it used in the decade of 90 in the sale of the functional properties of the Union. So that such exception could also be applied in DF, the local Executive would have that it presents a bill applying the rule to the lands of DF, what didn't happen, given the wide controversy concerning the model of sale of the lots. (CARVALHO JÚNIOR, 2007)

Still in January of 2006, TJDFT, assisting to a solicitation, through an injunction of MP, it suspended the habitation politics of DF. According to MP, the habitation politics in DF are composed for ordinances sent by the governor, what thwarts the Constitution. Still according to MP, the habitation public politics should be regulated by law, discussed and approved for CLDF. Obviously, after the suspension, several lawsuits, besides preliminary of the most varied appeared. In March of 2006, the public prosecution service looked for to guarantee in the justice that the to legalize of the irregular condominiums of DF was made through the public auction since according to MP the laws that back the direct sale are unconstitutional and that the sovereign devices are the ones that they foresee the competition. In March of 2006, the Union, through SPU, based on the time of the current occupant's of the earth home, besides following the Law 9.636/98 that it governs the patrimony of the Union, to structure a model for to legalize of your lands in DF. They would be entitled preferably the occupants that prove effective home before February of 1996. For the occupants of February of 1996 to the end of 1997, the criterion will be it of the public competition, but the resident, when equaling the financial proposal, it could be with the lot. The other cases, of residents that occupied the area after 1997, there would not be other middle to not to be through the auction. 
To the SIV-Água the task would fit of lifting the Areas of Permanent Preservation APP of the area and to present a report on the limits of the same ones, besides the constructions and constructions of the area. CAESB would take charge of demarcating the areas of pointed APP for the SIV-Água. SEMARH would fiscalize those stages, elaborating reports that would be given periodically to IBAMA.

After that stage, the SIV-WATER would coordinate operations of eradication of erect constructions in APP in the period of, at the most, one year after the signature of TAC, being that demolition one of the demands for emission of the installation license for the section. All the entities should to impede, continually, new invasions and constructions. Still according to TAC, after the demolitions, there would be a reforestation of the area with the planting of seedlings. In April of 2006, the SIV-Água concluded the demarcation of the residences that were in APP, besides the rising of all the constructions that should be demolished. In July of 2006, IBAMA began the notifications for the residents of those residences built illegally in APP to abandon her properties.

In July of 2006, the General Attorney's office of DF - PGR recommended IBAMA the suspension of TAC, alleging that GDF would not accomplish the activities, or either the awake calendar in TAC. IBAMA then gave period of five days so that GDF presented new action plan of having dropped for the constructions in APP, otherwise, it would suspend the license for installation of the net of water. Until the end of the month of July of 2006, only 12 constructions had been dropped indeed.

Arguing that it would not really get to accomplish the established goals in TAC, the SIV-Água requested a larger period to execute them dropped of residences in APP. However, the period of five days, stipulated by IBAMA it expired and the works of construction of water and sewers in the Agricultural Colony Vicente Pires were suspended, tends in view that GDF didn't execute activities and periods in TAC. In spite of the suspension and, without any answer of IBAMA, in September of 2006, GDF elaborated new action plan of having dropped, month in that TAC indeed would expire and the works of CAESB in the Agricultural Colonies Vicente Pires, Samambaia and Villa São José.

Several the factors that influenced the slowness of the process of operations of eradication of constructions were, necessary for the environmental licensing of the works. The countless ones preliminary granted to the residents, prohibiting to the actions of dropped on located houses in APP, the intense period of rains, and the terrible administration, human and administrative, on the part of GDF in accomplishing TAC, besides the traumatic and difficult process of eradication of inhabited constructions. The Brazilian State structure really failed in leaving the things they happen in the territorial occupation of the basin of the Samambaia's stream. The ideal would have to be avoided, but after having structured, the removal of those families is extremely difficult. A lot it is criticized organs as the extinct Siv-Água or now SUDESA, however only who the daily lived of eye to work in the eye with residents understands what is to be in that 
ingrate occupation and understands the Real meaning and consequences of the Brazilian State omission.

The discussion concerning the modality of sale of the lots is source of immeasurable discussions. Residents alleged that the auction would promote the speculation and that them, they buy the lots, they acted of good-faith tends, therefore, the right preferably in the purchase. On the other hand, TERRACAP affirms to be the landlady of the lands and, being state, your goods can only be sold in the auction form, in agreement with the law 8.666/93 - Law of Auctions and Contracts. In January of 2006, a commission created by GDF, constituted by representatives of TERRACAP, Company of Environmental Sanitation - CAESB, Energy Company of Brasília - CEB, Clerkship of Urban Development and House - SEDUH, General Attorney's office of DF - PGR, besides 05 integral of the Movement to Live Legal, they met in the attempt of directing solutions for the to legalize lander through the law of auctions and contracts. The largest prominence for the subject, is only point of consent of the commission it was that, for the irregular condominiums, it could be applied the Law 8.025/90, once, in your article 6th there is an exception. Such exception consists of granting to the current occupants preferably the right before the publication of a competition proclamation. There is still the period of 30 days for the current occupants to manifest interest or not in acquiring the good. The strongest argument, however, based on the allegation that that model was it used in the decade of 90 in the sale of the functional properties of the Union. So that such exception could also be applied in DF, the local Executive would have that it presents a bill applying the rule to the lands of DF, what didn't happen, given the wide controversy concerning the model of sale of the lots. (CARVALHO JÚNIOR, 2007)

Still in January of 2006, TJDFT, assisting to a solicitation, through an injunction of MP, it suspended the habitation politics of DF. According to MP, the habitation politics in DF are composed for ordinances sent by the governor, what thwarts the Constitution. Still according to MP, the habitation public politics should be regulated by law, discussed and approved for CLDF. Obviously, after the suspension, several lawsuits, besides preliminary of the most varied appeared. In March of 2006, the public prosecution service looked for to guarantee in the justice that the to legalize of the irregular condominiums of DF was made through the public auction since according to MP the laws that back the direct sale are unconstitutional and that the sovereign devices are the ones that they foresee the competition. In March of 2006, the Union, through SPU, based on the time of the current occupant's of the earth home, besides following the Law 9.636/98 that it governs the patrimony of the Union, to structure a model for to legalize of your lands in DF. They would be entitled preferably the occupants that prove effective home before February of 1996. For the occupants of February of 1996 to the end of 1997, the criterion will be it of the public competition, but the resident, when equaling the financial proposal, it could be with the lot. The other cases, of residents that occupied the area after 1997, there would not be other middle to not to be through the auction. 
However the public prosecution service, requested the Attorney general that judged a lawsuit against the model. The allegation for the lawsuit of the action was the that the Law 9.636/98 could not be applied, once to give the right preferably, to any that it is, in the purchase of a very public one thwarts the Federal Constitution and the Law of Auctions and Contracts, already mentioned. (CARVALHO JÚNIOR, 2007)

Concerning the environmental licensing, the proposal of the new law would be of an only document to exist, in other words, an integrated license, besides liberating small divisions, of up to 100 hectares, of the environmental licensing as it is done now.

In April of 2006, the Federal Government edited Temporary Measure, ${ }^{\circ} 292$ - call of MP Lander - that would allow the use cession and occupation of the soil in areas of the Union. However, your period to be voted by the National Congress expired and referred her MP didn't leave the paper, not resulting, therefore, any effect for the irregular occupations in Brazil and in DF. (CARVALHO JÚNIOR, 2007)

The rural producers, that indeed they produce fruits and vegetables, not only the one of the Agricultural Colony Vicente Pires, met in May of 2006 with the commission manager that is executing the revision of PDOT. In the meeting, the rural producers were positioned contrary the decision of GDF of transforming the remaining rural areas in urban area, as it consisted in the revision of PDOT, initiate for action of MP and executed by SEDUH. SEDUH was positioned favorable to the revindication, signaling that the rural properties that have more than 02 hectares will continue with rural characteristics, even if they are located in urban areas, I marry of Samambaia's stream basin. Still according to SEDUH, the proprietors will obtain the use title for more 30 years, since it doesn't parcel out. Only in the beginning of June of 2006, after more than 01 year after having firm agreement with IBAMA and residents, SPU restarted the activities foreseen for the to legalize of the area of Samambaia's stream basin. The first stage would be of registering the current occupants of the " small farms " of the Agricultural Colony Vicente Pires. To the whole, the process will understand:

" Properties Cadastrer, with the collaboration of the Army;

" Elaboration of EIA/RIMA, financed by the residents;

" Approval of project, also financed by the residents, but appraised and approved for SEDUH;

" Evaluation of the lands, for the Federal savings bank - CEF; and

" Sale.

SEMARH also began the attempt of regularizing busy areas irregularly in lands of GDF proceeding, basically, the procedures of SPU above mentioned and, a sweeping in the solicitation processes for emission of environmental licenses for the irregular condominiums. In that process the discussion began on the dismissal of previous license for condominiums already built and consolidated as measure and velocity for the 
subject lander of the irregular divisions into lots in areas of GDF. However, the main difficulty of that process was to delimit that organs legislate on which areas, if IBAMA or SEMARH, tends in view DF a mosaic of protected areas to be considered. In August of 2006, the proposal appeared of containing condominiums as habitation sections rendered road entrance. The proposal would reduce, therefore, stages of the environmental licensing, determining that the divisions into lots are not analyzed individually, in other words, they group condominiums, considering the habitation section that they form together. According to the Entrance, there will be an elaboration of the occupation plan and TR for the environmental study of the area to be licensed. Soon after, they will execute the studies s and you adapt. Such studies will be analyzed by CONAM.

Being approved, it will happen the signature of the Term of Commitment for accomplishment of the infrastructure works and measures for reduction of the environmental damages. Accomplishing that term, emission of the environmental licensing and approval of the plan. Finally, I register cartorial to legalize and implantation of the pertinent works. In spite of being in consonance with the effective legislation and aiming at to facilitate the execution of studies s and you adapt, such entrance doesn't have law force. It should be introduced to the residents, for emission of suggestions and, only after the agreement of both parts, it should be signed by the titleholders of SEDUH and SEMARH. It is an extremely feasible proposal, however, with the extinction of SEMARH, in the beginning of 2007, the model is stopped in your administrative procedures and without retaking forecast in the negotiations. (CARVALHO JÚNIOR, 2007)

Before of that sinuous lander scenery of DF, there was the bill approval that extended the validity of the environmental licenses emitted by the competent organs. In the bill, the previous licenses, of installation and of operation they start to be worth for five, six and ten years, respectively. Before, the period to accomplish the demands of all those licenses was of one year. With the objective of moving forward to legalize processes, GDF published Entrance, in September of 2006, that allows to the occupants of irregular divisions to give beginning to the studies $\mathrm{s}$ while the environmental processes are analyzed by the competent organ, IBAMA, in areas of the Union and SEMARH, in areas of GDF.

In December of 2006, SIV-Água and the company that it is elaborating EIA/RIMA of the Agricultural Colony Vicente Pires announced that, together, they will make a new study to delimit areas that are in APP, once the first study of the SIV-Água appeared about 549 constructions in APP. The intention of the new study would be to delimit, precisely, built houses the less than 30 meters of bodies of water and 50 meter of East, as foresees the environmental legislation.

\subsection{Conflict Structure}

It was noticed in the development of the research that for a cash understanding of the use and territorial occupation of Samambaia's stream basin and your conflicts would be 
necessary a critical focus of the environmental " subject the conflicts they are put at a stage - the basin - in which to be opposes different social groups - actors - in asymmetric conditions of being able to and struggling for the attribution of different meanings and territorial uses.

That process of social division does with that the system of the conflict object if it moves of an optics " biologic " as, for instance, I use of the resources waters of the basin or the integrity of the areas of permanent preservation, for a sociological " point of view ". What happens in that basin, it transcends the maintenance of the maintainable of a river for an expression of originated social fights when the actors notice threats in the social forms of appropriation of the middle in that live for undesirable interventions (views in a broad way) current of the exercise of the practices of other groups. That places on the agenda environmental " conflicts " for the appropriation of constituent elements of the base reproduction of social groups. (CARNEIRO \& BARROS, 2006)

That vision contributes to a geographical approach of the conflict, approached the territory " concept that includes the practices and social conflicts of material and symbolic appropriation of private natural conditions. And in the conjuncture of a capitalist society it is noticed an unequal distribution of the access possibilities, control and use of the different territories, as well as the social fights around that distribution. That model of " territorial " inequality is expressed in the urban atmosphere, in the space distribution of the population, where poorer layers are pushed " for areas in that they ponder the problematic effects originating from of the action of dominant social groups, such as floods, sinking's, tumbling's, lack of equipments of basic sanitation, collects and garbage treatment and sewer. (CARNEIRO \& BARROS, 2006)

Therefore, in the perspective of the paper of the environmental conflicts in the construction of urban territories, starting from a case study that tried to reconstitute the processes and conflicts that result in the current form of occupation of the territory of Samambaia's stream basin, in DF.

It was noticed that the formation of the urban territory in Samambaia's stream basin (process of transformation of remaining rural area for urban area) inhabited for popular classes, it results of the interaction of the urban of the inequalities generated by the:

a) market economy;

b) for omissions and selective actions of the Brazilian State;

c) for the fights and organized collective practices for the population.

These pronouncing the other actors, they look for to promote forms of appropriation of the territory and provision of infrastructure services in agreement with your interests. That that the societies do with your material middle is not summarized to satisfy lacks and to overcome material restrictions, but it also consists of projecting in the world different meanings - to build landscapes, to democratize or to segregate spaces, to standardize or to diversify social territories. (ACSERALD, 2004).

Eletronic M agazine: Time - Technical - Territory, V.3, N.1 (2012), 101:143 ISSN: 2177-4366 
For the that was said, no matter how much the clear and explicit interventions as constructions in areas of permanent preservation, contamination of the rivers and nascent, conflicts between GDF and residents in the operations of eradication of constructions, among other, describe the most direct moment for the which the actors transform the biophysical way, it is important to understand that those interventions are conditioned by the social and cultural forms, in other words, for the options of the society of DF in a model and a culture of territorial. In that way, the conditions of production of the space in Samambaia's stream basin, are the field of relationships that the groups interweave in the social space, in the own visions of the social world and of your relationships with the nature. In relation to that understanding becomes necessary to emphasize the type of power between the different participants of the conflict and the antagonisms among interests, the symbols and world vision's besides the social relationships, politics and economical among the involved actors and to identify the existent environmental impacts or potentials. That need elapses of the fact that usually the conflicts environmental in the territories and all the uses and senses attributed to the middle, they interact and they are connected materially and socially be through the waters, of the soil or of the atmosphere. (LITTLE, 2001, NASCIMENTO, 2001)

To approach a environmental conflict leaning on in the territory concept in the group to the territory idea, built by practices of appropriation of the resulted world of the relationship among geographic, ecological organization and cultural significance, that are delineated through cultural identities and in the way of appropriation of the nature. The territory can be defined like this as the collective effort of a social group to occupy, to use, to control and to identify with urn parcels out specific of your atmosphere, turning like this into your " territory ". it is a latent force in any group, whose explicit manifestation depends on historical contingencies, needs and demands. (LITTLE, 2001)

The human has a multiplicity of expressions, what produces a very wide fan of types of territories, each one with your social and cultural particularities that each social group uses to establish and to maintain your territory, as your property regime, the history of your occupation kept in the collective memory, the social use that gives to the territory and the forms of defense of him. (LITTLE, 2001, NASCIMENTO, 2001)

Therefore the space concepts of territory, more and more, the intimate relationship between the urban subject and the environmental subject. Therefore, the analysis of the urban with a " environmental " glance should be centered in the appropriate life conditions to the communities, emphasizing your relationships with the social diversity and of the atmosphere where live - with your territory; territory fruit of the collective effort that a social group occupies, uses, it controls starting from your biophysical atmosphere - as construction of your territory. (MONTE-MOR, 1997).

Before what it was exposed up to now it is possible to notice that the transformations in the understanding of the use process, appropriation and economical organization of the territory place the urban space as a result of deep transformations on the physical middle along the times, of the which the case of Samambaia's stream basin, is more one in DF. 
It is the historical process of occupation of the territory, as your transformations, in a certain time or society that does with that the environment has a dynamic character, because the space is movement. (SANTOS, 2005)

For a more lucid understanding on the environmental conflicts in Samambaia's stream water basin, it is important to consider that environment ( basin or physical support) it is, also, social and historically built, conditioned and of the movement transformer of the social life. Therefore, in the study of the urban environmental conflicts it is not possible to separate the society and your physical atmosphere, since the two dimensions constitute a socialized material world and endowed with meanings. However, due to false two ways between the environmental and the urban a certain incompatibility was been between urban planning and environmental planning, to the point of the section of urban development (development of the built habitat) and the one of environmental politics (politics related to the natural resources) they exercise command, per times, conflict inside the own apparel of been Brazilian, resulting in disjointed and inefficient politics (RABBIT, 2005).

Being exemplified, it is perceptible that in the inhabited urban areas for more privileged sections in DF, the occupation of the territory tends to obey previously to patterns defined and the provision of basic services of urban infrastructure is accomplished, under the form of rights for the Brazilian State, more quickly and in an integral way. On the contrary, in the areas in that live the subordinate classes the occupation process it tends to be erratic, dependent of the mobilization of the population and of the other actors' support, as typical example the condominiums that disperse for every DF. In Samambaia's stream basin, the path of formation of the territory and of obtaining of infrastructure services it is revealed a succession conflicts, failures and conquests, many partial times and subject to setbacks. In that sense, the elaboration of models of analysis of the patterns of construction of urban territories of popular classes should not just consider the paper of the Brazilian State and of the determinant of the market economy, but also, as inherent to such patterns, the own practices and fights of territorial appropriation begun by the inhabitants of those territories.

That is very perceptible in the adjacencies of the basin in study, because crossed by the road Highway Taguatinga, they are had on a side the neighborhood of Águas Claras that is a section drifting in thesis, with constructions for the public of high middle class and of the other the call habitation section Vicente Pires, that is contained in Samambaia's stream basin . Just for a highway, it is noticed the invisible and tacit wall of the social inequality. On a side a neighborhood in effervescence, as public services as subway, commercial centers and university and of the other side, a neighborhood was constituted, lacking of minimum basic infrastructure.

The head offices of that really different healthy conflict, there are a dispute of forces and powers. It exists on a side a middle class that possesses interests directly conflict with the proprietors of the urban earth (public or toilet). That conflict, therefore, says respect mainly, to the real estate speculation. On a side, the middle class looking for 
wide and cheap spaces, of other, the urban earth being speculation object, allies the an absence of habitation public politics. (CARVALHO JÚNIOR, 2007)

The speculation lander is not of interest of the middle class, but fundamental in the dynamics of the "grileiros" (salesperson of irregular earth), since in reality of DF the great majority of the lands is public. As sees, the absence of public politics creates an offer shortage and a demand that it presses, making possible to enlarge them the income of the earth. That conflict, usually, it is solved by pressures of the classes involved in the Brazilian State.

Those pressures suggest infrastructure implantation, dispossession of lands and habitation politics directly for the population involved. Those agents act in the urban space seeking to obtain the largest profitability in the use of the earth. Given that the urban earth has larger value than the rural earth, these agents are mobilized aiming at the transformation of rural areas in urban. The initial interest relapses on the agricultural periphery, once the proprietors land desire to transform in urban, what will generate, for consequence, valorization lander.

However, that passage of rural area for urban area is not simple, involving differentiates of demands of lands and houses, of the emergence of new layers social, proceeding partly of migratory flows and that stops level of income that is qualified them to participate in the market of lands and houses. It also depends on the possibilities of remuneration of the capital invested in lands and real estate operations and still of the politics that the Brazilian State adopts to allow the reproduction of the capital, as reinforcement of the apparel of the Brazilian State for the increase of the number of employees and through the ideology of the own house. (CORREAA, 1989; CARVALHO JÚNIOR, 2007).

Factors as agrarian structure and of the futures uses they be her given to the area they are also important in that process. Areas rural, susceptible to speculations, tend to be more sought. Already flooded areas, for instance, tend to hinder the process of valorization lander longed for by these agents. These agents also unchain other processes of valorization lander. It is treated of a type of special of areas, with treatment differentiated before to neighborhoods abandoned, in other words, a make-up of a certain area, together with advertising campaigns, seeking to give a new status to a certain neighborhood, so that, the main objective is the valorization lander. In this point, it fits to point out that these agents, on that moment, act also as real estate promoters, because at the same time in that it stops the ownership of the earth, also to build, lot, they fraction. It is noticed that there is not interest of the proprietor to change in real estate promoter, however, in the division it is that the proprietor obtains a maximized valorization.

The fact of we be in a capitalist society, it foments differentiations of classes, of incomes and other linked aspects to the capitalist scenery of accumulation. The house, also, interferes in that scenery, once the access to her is selective: nor all have enough income to pay a rent at least, the more to acquire a property. The ones that have a 
monetary income that it makes possible a financing at least, they have enormous difficulties to execute and to accomplish not even that the ones that has, they leave for the illegality of the irregular occupations. That model of the urban space, on the part of the social groups, feels in a survival character and also as a resistance form. Survival many times for they be excluded inside of the actions of the Brazilian State of the habitation politics and resistance for these agents' fact to long for to show the interest for the access to the city, resistance that a lot of accompanied times of mobilizations in mass. (CORRÊA, 1989)

The location of the busy areas for these agents, initially, they can seem disparate, as in the case of the basin of the Samambaia's stream, however, there is a logic, tends in view that your action if starter seeking to solve two critical problems: the one of the house and the one of the accessibility to the work place.

In the irregular occupations, it shows as it is uncoiled, usually, the urbanization process that results, on a side, of the own residents' action that, little by little, during a long period of time, they are going improving your residences, implanting several economical activities. Of other, it occurs of the action of the Brazilian State, that it implants some urban infrastructure, be starting from pressures exercised by the organized residents in associations, be starting from politics interests. This urbanization, however, it unchains a valorization that ends for to expel some of your residents and to attract other, as it is happening in the area. (CORREA 1989; CARVALHO JÚNIOR, 2007)

The complexity of the several agents' actions that produce the urban space, your fields of performance, convergences and conflicts were here exposed and, of that discussion it is noticed, practices use capitalists and occupation of the soil, always seeking the profit and the income to be obtained through the urban earth on the part of the first three exposed agents. The social groups, not stopping a substantial capital, they are excluded of the process, happening the principal reason of your constitution then looking for, like this, the attendance of your revindication for access to the home, be them for the lowest layers or averages.

The capitalist conception that emanates in reality of the territorial occupation in Samambaia's stream basin, doesn't embrace the social character, bringing with itself occupations, that besides irregular, they bring shameful levels of transgressions to the laws landers, impunity sensation, proliferation of Mafia of "grilagem" of lands and the total disrespect to the environment, that last one, the central aspect of this study.

Another interesting aspect in that discussion is that it was also noticed the lack of theoretical works on the urban environmental conflicts in DF, even before the crescent number of cases susceptible to study. Therefore the challenge is imposed of doing with that the present study of in case it is more than descriptions of the empiric interactions among social groups that produce the territories. 
The constitution of that environmental conflict is in the model of territorial administration adopted by the Government of Distrital, favoring the mechanisms producing of environmental inequalities. This placed the populations of low income in the contingency of they have to work several strategies of individual and collective action to obtain, the provision of the services and urban equipments of consumption, the ownership of the soil, the house, the environmental safety etc. The programs of establishment of the populations of low income proceeded without a lot of criterion.

The people were placed in "new cities" without the offer of the basic services. Being that "insufficient program" to assist all to the habitation demand, grew up the "logic and the culture" of the invasion of the public earth. That phenomenon, associated to the Brazilian State omission, stimulated the coming of several "bombs clock" ready to explode to the first sign.

The model of the "condominiums" that was adopted not only in DF as well as in several states of the federation, it is an expression of the absence of the Brazilian State in the provision of habitation politics, in the not effective provision of urban equipments of infrastructure and collective consumption and also to the fiscalization difficulties.

With effect, the public power, when it attends, does pressed and for the conflicts played by the organized population or for processes of "to legalize lander" where since it is not known who is the owner of the earth, she will always be property of the Brazilian State. The responsible agency for that sale process and lot to legalize in DF is TERRACAP that sells them to the residents or opens auctions, whose prices are reply objects and litigation on the part of the residents.

In the territorial model of the "condominiums" largely, the social construction of the urban territory was made by the contest of strategies and actions undertaken by the own local population and for other social actors. The action slanted of the Brazilian State and the market mechanisms worsen the picture of environmental inequality with that the studied population is confronted. In that picture, the local population stays along the time in permanent state of alert and mobilization, to obtain of the public powers the provision of the services of urban infrastructure. Being accompanied the temporary accompaniment of the use and territorial occupation was possible to notice the population growth in Samambaia's stream basin, provoked, partly, for the vegetative growth, and, partly, for the new residents' arrival - attracted for the reached urban improvements and for the relatively lowest costs of home - it carts the need of new mobilizations and conflicts. In that sense, the environmental conflicts are constituent elements of the own pattern of social construction of the inhabited urban territory for population of the basin.

Head offices of the Partner-environmental Conflict 
Environmental Head office:

Strip of 30 meters protected by the Brazilian Forest Code, where in reality of Samambaia's stream basin is not permitted the presence of constructions in your margin. Those areas are of forbidden and priority use for conservation. The eradication of present constructions in those areas is fundamental requirement for the environmental licensing of the neighborhood, and it has been used as argument for disputes and political wastes between GDF and Union. The constructions in her existent, they cannot receive the improvements of basic infrastructure as water, it shines and sewer. They are mainly inhabited areas for people of low income.

Lander Head office: The Subject of the Ownership of the Earth

The lander head office is without a doubt fundamental requirement, since it is still confused the subject of the ownership of the earth in the Basin. Union and GDF didn't still present a polygonal egg white, the limits of each ownership. The initial residents received the small farms in the lease form. However those were sold, resold and fractional for the decades, still increasing more the difficulty of clearing the ownership of the earth. The strip of 30 meters protected by the Brazilian Forest Code, it was the fuse of the conflict. Those areas are of forbidden and priority use for conservation. For the areas out of APP GDF begins a model of regularização questionable fundiária.

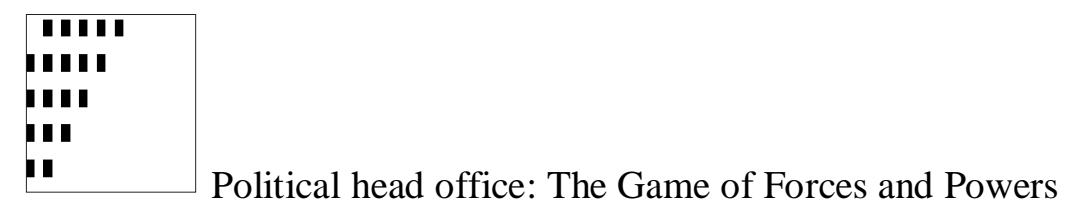

Without a doubt a delicate theme of being treated, but the subject of that conflict has been serving as excuse for wastes between the Union and GDF, in the moment of opposite political parties. The Justice determines the eradication of constructions, the Union it collects and GDF, that executes, says that the eradications are and difficult of they be done. Periodically they appear political distritais in defense of the population of the basin. They appear in the day of the eradication operations, and they cause tumult, hindering the work. Some use that for if they promote in the area. The cultural head office refers to the model of territorial occupation by which went Distrito Federal in the last decades. The coalition of absence of coherent habitational politics, allied to a habitational demand, it fomented the real estate speculation and the culture of the invasion of the public earth. 


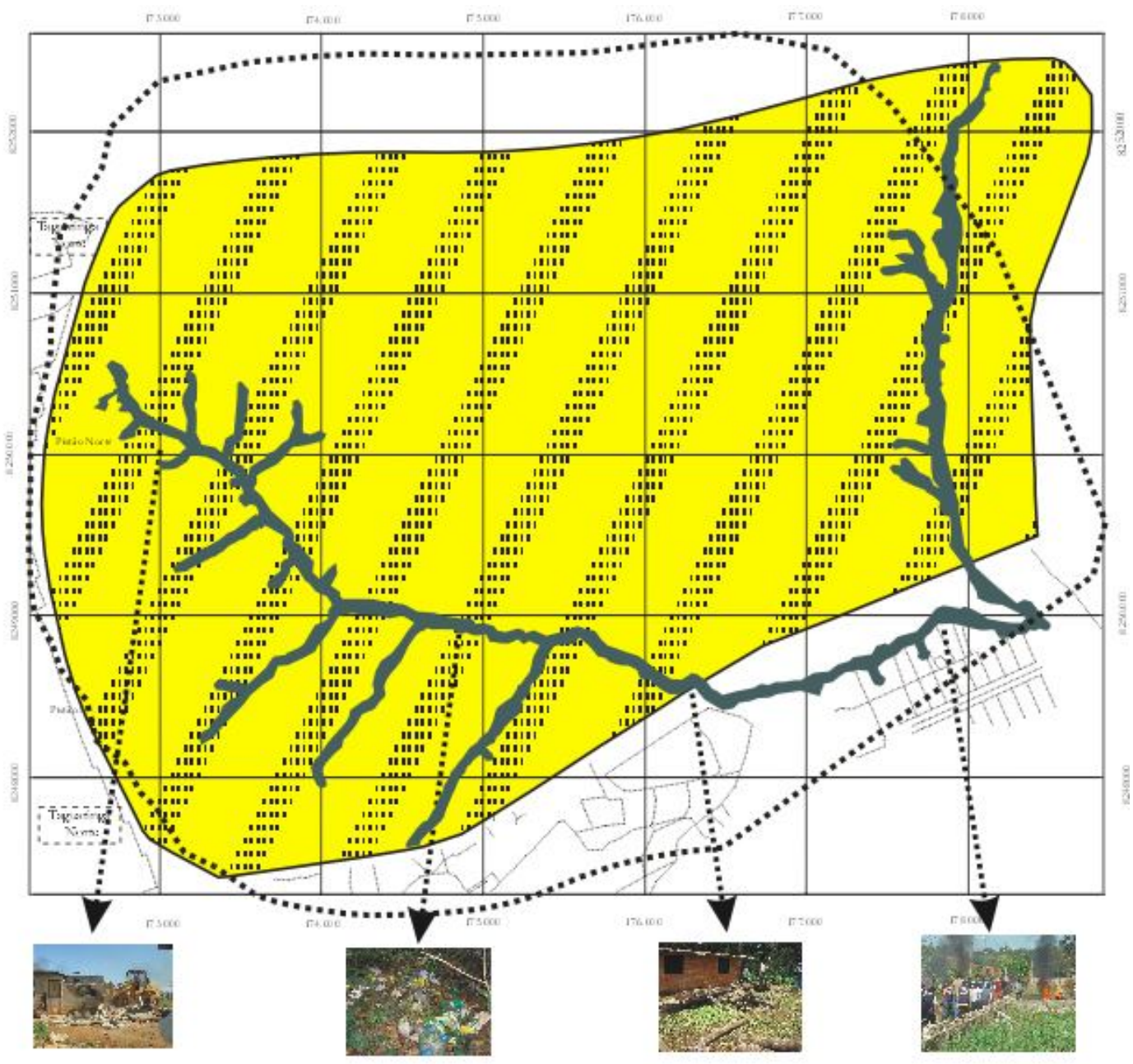

\section{Conclusions and Recommendations}

With the present work it was noticed that irregular occupations are generating sources of environmental liabilities in urban areas that contribute to the change of the natural way of the great cities.

The access difficulty to the earth for legal means stimulates part of the society to look for other mechanisms, for illicit times, to satisfy your habitation demand. The deficit, caused by the administration incapacity by Brazilian State part, added to migratory processes and the real estate speculation it foments the compromising of areas of permanent preservation and the appearance of environmental conflicts in Samambaia's stream basin.

It is that state absence, that stimulates the solemnity-organization of the populations in the irregular divisions into lots in mass or "condominiums" are seen paradoxically as a solution model legitimate and appropriate to solve the habitional demand, and nevertheless to gain enormous won political with those mistakes for, to proceed, to spend fortunes of the public money "to repair" the damages environmental, social, landscaper, patrimonial, of infrastructure, generated. 
The favorite areas for the irregular division are them found in Remaining Rural Areas, since they are still not areas consolidated in urban and susceptible to division. The largest problem found in the division of these areas it is the fact that, in your great majority, they are located in areas whose half natural has more sensitive characteristics and that still develop activities of your original vocation.

The game of the involved actors' interests was heterogeneous in the place. It is believed that those actors' action was fundamental to understand the constitution process and evolution of the conflict. Another fundamental requirement is to visualize that the principal agents were not chosen in the beginning of the process, but they were constituted and they settled down gradually during whole the process.

The Areas of Permanent Protection (APP) of the basin of the Samambaia's stream: forests galleries, nascent, rivers that cut the place, areas with steepness above $30 \%$, need, largely, they be protected and recovered as fundamental requirement for the process of licensing of the habitation section contained in the basin in study.

The mediation and resolution of the conflicts occurrences in Samambaia's stream basin, goes by the recognition of the interrelations, between the dimensions economical, social, environmental, cultural and existent politics. For so much, becomes fundamental that a posture of horizontal relationships exists, which should promote, among other things, the collective participation in the mediation process.

The conflicts in Samambaia's stream basin passed of the initial apprenticeship of potentials or latent, where the structural factors of the litigation were conditioned, but without the contention fully established, for obvious conflicts, where the actors in the confrontation take measures of defense of your interests, the times in detriment of the solution and restricting the dialogue search and mediation. It is curious to notice that was the beginning of the process of environmental licensing exactly (a legal instrument) of the neighborhood that deflagrated that contention, by the need of eradication of constructions in areas of permanent preservation.

The largest challenge for administration of that conflict is it of as the actors create a mediation mechanism that establishes the model recommended by Nascimento (2001), of " having win-won ", where all the actors' longings are at least partially assisted, and none of them feels prejudiced or ignored in the process of search of the consent. As it was noticed that some parts just look for the defense of your interests, the solution is the medium or long period.

In the studied case, the best form of resolution of the conflict would be your administration and among the resolution types presented by Little (2001) the one of the cooperation would be the most appropriate. For conflict situations on maintainable development the groups in litigation need dialogue for us to arrive to consent, however needing a mediator, that in the case of the Water basin in study, it is the public prosecution service by the Term of Adjustment of Conduct (TAC). 
In that conflict they wrap up actors of several slopes, with asymmetric relationships of being able to and where the relationship between the environment and the society is in game. In that handling of the forces being looked for the mediation of that conflict important factors in the healthy process: the) to improve the processes of electric outlet of decisions; b) to promote spaces that allow equal agreements; c) to reaffirm the power and the involved actors' legitimacy; d) to offer a process of transparent mediation; and) to commit the actors with the awake results and f) to deflagrate a learning process on the validity of the dialogue as form of to face and to prevent conflicts.

\section{Bibliographical References}

ASCERALD, HENRI. Conflitos Ambientais no Brasil. Rio de Janeiro: Relume Dumará: Fundação Heinrich Böll, 2004.

CARNEIRO, EDER JURANDIR \& BARROS, MATHEUS ALVES DE Conflitos Ambientais e

Construção de um Território Urbano: O Caso do Bairro São Dimas (São João delRei - MG) III Encontro da Associação Nacional de Pós Graduação e Pesquisa em Ambiente e Sociedade. 23 a 26 de maio de 2006. Centro de Convenções Israel PinheiroBrasília - DF - Brasil

CARVALHO JUNIOR, WILSON MARTINS DE Os impactos ambientais decorrentes da ocupação urbana: o caso da Colônia Agrícola Vicente Pires - Brasília/DF, 203p., 297 mm, (UnB - GEA, Mestre, Gestão Environmental e Territorial, 2007). Dissertação de Mestrado - Universidade de Brasília. Departamento de Geografia.

COELHO, M.C.N. Impactos Ambientais em Áreas Urbanas - Teorias, conceitos e metodologia de Pesquisa. In: GUERRA, A.J.T \& CUNHA, S. B.(Prgs) Impactos Ambientais Urbanos no Brasil. $3^{\circ}$ ED. Rio de Janeiro: Bertrand, Brasil, 2005.

CORRÊA, Roberto Lobato. O espaço urbano. São Paulo: Ática, 1989. 94p.

CORREAA, ROBERTO LOBATO; ROSENTHAL, ZENY. Paisagem, tempo e cultura. Rio de Janeiro: Editora UERJ, 1998.

FAUSTINO, J. Planificación y Gestión de Manejo de Cuencas. Turrialba: CATIE, 1996. 90p.

HAESBAERT, ROGÉRIO. Região, diversidade territorial e globalização. GEOgraphia - Ano. 1 - No 1 -1999. 25p.

LEFF, HENRIQUE. Saber Environmental: Maintainable, racionalidade, complexidade e poder. Trad. Lúcia M. Endlich Orth. Petrópolis: Vozes, 2001.

LITTLE, PAUL. Os conflitos socioambientais: um campo de estudo e da ação política. In: Bursztyn, Marcel. A Difícil Maintainable. Rio de Janeiro: Garamond, 2001. 
MACIEL, SÔNIA MARIA BAENA. O Processo de Ocupação da Colônia Agrícola Vicente Pires: ação antrópica e impactos ambientais. Dissertação de Mestrado Programa de Pós-Graduação Stricto Sensu em Planejamento e Gestão Environmental Universidade Católica de Brasília. Brasília, 2001, 140 f il.

MONTE-MOR, R.L.M. Urbanização Extensiva e Lógicas de Povoamento: um olhar environmental. In: SANTOS, M; SOUZA, M.A. de \& SILVEIRA, M.L. (Orgs.) Território, Globalização e Fragmentação. São Paulo: Hucitec, 1994

NASCIMENTO, ELIMAR. Os conflitos na Sociedade Moderna: uma Introdução Conceitual. In: Bursztyn, Marcel. A Difícil Maintainable. Rio de Janeiro: Garamond, 2001.

RAFFESTIN, Claude. Por uma geografia do poder. São Paulo, Ática, 1993.

SCHIER, RAUL ALFREDO. Trajetórias do conceito de paisagem na geografia. R. RA'E GA, Curitiba, n. 7, p. 79-85, 2003. Editora UFPR.

SANTOS, M. A natureza do espaço. Técnica e tempo. Razão e emoção. São Paulo: Hucitec, 1997.

SANTOS, Milton. O Pensamento, Encontro Internacional Espécie, Espaço, Estado - ou Desafio do Ordenamento Territorial. Disponível em: <www.alfa.br/revista/pdf/7tur.pdf>. Acesso em: 20 maio 2005.

SOUZA, E. R. de; FERNANDES, M. R. Sub-bacias s: unidades básicas para o planejamento e a gestão sustentáveis das atividades rurais. Informe Agropecuário, Belo Horizonte, v.21, n.207, p.15-20, nov./dez. 2000.

TROLL, C. El paisage geográfico y su investigación. MENDONZA, J. G. ; JIMENEZ, J. M. y

CONTERO, N. (Org.) El pensamiento geográfico. Estudio interpretativo y antologia de textos (De Humboldt a las tendências atuales). Madrid: Alianza Editorial, 1982.

UNESCO. Vegetação no DF - tempo e espaço. Brasília, 2000, 74p. 